\title{
FOUR RECORDS OF NEW TO EGYPT GASTROPOD SPECIES INCLUDING THE FIRST REPORTED TROPICAL LEATHERLEAF SLUG LAEVICAULIS ALTE (D’A. DE FÉRUSSAC, 1822) (PULMONATA: VERONICELLIDAE)
}

\author{
Reham Fathey Alia, b and David Gwyn Robinson ${ }^{\mathrm{e}^{*}}$
}

\begin{abstract}
${ }^{a}$ Department of Zoology and Agricultural Nematology, Faculty of Agriculture, Cairo University, El-Gammaa St., 12613; Giza, Egypt; ${ }^{b}$ Faculty of Organic Agriculture, Heliopolis University for Sustainable Development, 3 Cairo-Belbeis Desert Rd, El-Nahda, Second Al Salam, Cairo, Egypt, 11785, P. O.: 3020; ' USDA APHIS PPQ National Identification Services, National Malacology Laboratory, Academy of Natural Sciences, Philadelphia, Pennsylvania, USA

*Corresponding author. Email: david.g.robinson@usda.gov
\end{abstract}

\begin{abstract}
Article history
Received: 4 March 2020; accepted 11 November 2020
\end{abstract}

\section{Keywords:}

Invasive; terrestrial gastropod; abundant pests; snail; slug; Egypt

\begin{abstract}
A survey of terrestrial mollusks was performed during their activity season in various spots of gardens, nurseries and agricultural fields in Cairo, Giza as well as in some neighboring areas between December 2014 and October 2018. Several invasive terrestrial gastropod species were identified. These gastropods are invasive and abundant pests causing considerable and serious damage to agricultural areas in the Nile Delta Region of Egypt. The specimens were collected from different locations in the governorates of Cairo and Giza. A total of 12 species ( 8 species of terrestrial snails and 4 of slugs) were identified by their shell characteristics and genital-anatomical characters. The following four species were identified for the first time in Egyptian gardens and nurseries: 1) Polygyra cereolus (Megerle von Mühlfeld, 1816), 2) Oxychilus cf. cellarius (O. F. Müller, 1774), 3) Zonitoides arboreus (Say, 1816) and 4) Laevicaulis alte (d' A. de Férussac, 1822), which is particularly injurious to agricultural production. The other invasive species reported in this study were recorded in other agricultural fields and are common pests of gardens, nurseries and agricultural areas in Egypt. This study presents essential information on each species, their original and current distribution in Egyptian agricultural fields.
\end{abstract}

\section{INTRODUCTION}

Numerous species of terrestrial gastropods are economically important as agricultural and horticultural pests in the Nile Delta Region and occur in high numbers in the North Coast belt of the Mediterranean Sea (Kassab and Daoud 1964; El-Okda et al. 1977; El-Okda 1980; Nakhla and Tadros 1995; Mahmoud and Awad 2008; Mohammed 2015) as well as in other countries of the world (Godan 1983; Frank 1998; Baker 2002, 2008; Davis et al. 2010).

A number of these species are already known as serious pests of agricultural and ornamental plants in greenhouses, nurseries and gardens and are agriculturally important in the Nile River Delta Region including the governorates of Cairo, Giza, Alexandria, Beheira, Sharkia, and Dakahlia (El-Okda 1979; Hashem et al. 1993; El-Deeb et al. 1999; Mahrous et al. 2002; Genena 2003; Daoud 2004; Mohamed and Ali 2009; Ali 2011).

This region represents a major pathway for the movement of non-native terrestrial mollusks, because it both imports agricultural produce from the rest of the world (Baker 2002; Sallam and El-Wakeil 2012) and exports agricultural goods from Egypt.
Most previous studies focused on Massylaea vermiculata, Theba pisana and Monacha obstructa as the most prevalent and widespread species in the Egyptian agricultural environment increasing economic losses due to their activity, population density, feeding habits and successful adaptation to the new climatic conditions, which are not similar to those in their original environments (Mahrous et al. 2002; Ismail et al. 2003; Mahmoud and Awad 2008; Mohamed and Ali 2009; Sallam and El-Wakeil 2012).

These pests inflict damage to cereals, field crops, seeds of oil plants, medicinal and ornamental plants, citrus, mango and peach orchards, palm trees and vegetables such as cabbage, carrot and beans (El-Okda 1979, 1981, 1984; El-Deeb et al. 1999; Ismail et al. 2003; Lokma 2007; Shahawy et al. 2008).

Furthermore, animals avoid feeding on plants contaminated with snail slime. As a result of snail slime contamination, the consumption value of plants reduces (Kassab and Daoud 1964; El-Okda 1984), agricultural crops lose their marketing properties and their export potential in different international markets (Baker and Hawke 1990; Ittah and Zisman 1992). 
Monacha obstructa has been recorded as the most widespread agricultural pest of different field crops, fruit orchards, vegetables and ornamental plants in the Delta Region (Kassab and Daoud 1964; El-Okda 1984; Hashem and El-Halawany 1996; Mahrous et al. 2002). In addition, it is of veterinary importance as an intermediate host to trematode parasite, i.e. Brachylaima (Rashed et al. 1995; Wanas et al. 1995; Rashed 2008), nematode parasite Angiostrongylus cantonensis in Egypt (Yousif and Ibrahim 1978), and other agents of parasitic diseases that affect humans and animals worldwide (Godan 1983).

Economic damage is caused not only by terrestrial snails, but also by terrestrial slugs, which are recorded as serious pests of agricultural crops and ornamental plants in multiple spots in Delta River Region governorates. They mainly inhabit more humid and shady places such as green houses and nurseries (Lokma 2007; Ali 2011; Rady et al. 2014; Abou Senna 2016). The slugs Deroceras reticulatum and $D$. laeve were first recorded on Egyptian clover in Meniet El-Kamh and Zagazig districts, Sharkia governorate (Lokma 2007). As reported by Rady et al. (2014) D. laeve and $D$. reticulatum infest different crops in the governorates of Ismailia and Sharkia, the latter species being first recorded in the Ismailia governorate. The destructive impact of these pests is far greater today than it was in previous years, which is due to the ever-increasing traffic congestion and flow.

Limacus flavus is one of the slug species recorded in Cairo gardens and nurseries (Azzam 2003; Mohamed and Ali 2013).

In recent years, surveys of mollusks with a focus on their feeding habits and financial losses caused to farmers due to the damage inflicted by gastropods have been carried out in different governorates of Egypt, i.e. in the governorate of Ismailia (El-Okda 1984), in new reclaimed lands in the northern region of Egypt (Hashem et al. 1992), in governorates of Beheira (Hashem et al. 1993; El-Deeb et al. 1999), Sharkia (Hegab et al. 1999; Mahrous et al. 2002), Gharbia (Metwally et al. 2002), Kafer El-Sheikh (El-Deeb et al. 2004), Dakahlia (Genena 2003; Daoud 2004), Damietta (Mahmoud and Awad 2008), the governorate of the Suez canal and that of South of Sinai (Shoieb 2008), the governorates of Ismailia, Qalyubia, Monufia (Mohammed 2015), and Assiut (Ramzy 2009).

Until now, there has never been a comprehensive survey of terrestrial mollusks in the Nile Delta Region of Egypt performed or a complete list of non-native terrestrial mollusks compiled. Their predatory or omnivorous behavior has not been studied either.

This study was undertaken with a view to obtain the first-hand knowledge of the gastropods present in agricultural-productive areas in Egypt, and to document the agricultural impact of these pests.

\section{MATERIALS AND METHODS}

Terrestrial mollusks were collected from nurseries, gardens and agricultural fields in the governorates of Cairo, Giza, Qalyubia and Monufia between December 2014 and October 2018. Mollusk sampling was conducted at thirty-four sites in the evenings and in the early morning hours in relatively cool and humid conditions, when slugs and snails were most active. Larger specimens were usually found on ornamental plants, while smaller specimens in humid areas, e.g. near irrigation tubes, close to water faucets, in leaf litter, and under stones.

The gastropod survey locations, where numerous specimens were collected and numerous species of land mollusks were recorded, are given in Table 1. They include the governorates of Cairo, Giza (Faculty of Agriculture Cairo University, Shabramant, El-Saf, El-Hawamdia, ElAyat, El-Badrashin, Abo Rawash, El Mansouria village), Qalyubia (Qalyub - El Qanater El Khayreya - Shubra El Kheima), and Monufia (Ashmoun - El Bagour).

Most gastropods were collected in cool cloudy weather from the soil surface between plant crops, seedlings, plant pots, logs, leaves and stems whether from gardens, nurseries, green houses or from agricultural fields.

The collected specimens were kept in labeled plastic containers, lined with moist paper towels, and then transferred to the laboratory of the Zoology and Agricultural Nematology Department, Faculty of Agriculture, Cairo University. The collected gastropods were kept in containers with moist soil.

The snails and slugs were drowned in cold water for 10-12 hours, or until no response to external stimuli was received, after which they were transferred to $80 \%$ nondenatured ethanol. The tentative species identification was made based on the external appearance, including shell characters, and was confirmed by the second author, who performed the analysis of their dissected genitalia. The examined specimens were assigned to the following species: Deroceras laeve, Ambigolimax valentianus, Laevicaulis alte, Monacha obstructa, Cochlicella acuta, and Oxychilus cf. cellarius although the specimens assigned to the latter species were not mature enough for final confirmation.

Specimens of all twelve species were vouchered in the collection of the Faculty of Agriculture, University of Cairo, Egypt, and in the USDA APHIS National Malacology Collection in Philadelphia, USA.

\section{RESULTS}

Twenty-two out of the thirty-four sites surveyed in this study harbored more than 60 specimens representing 12 terrestrial mollusk species, most of which are synanthropic and invasive alien. These mollusk species with 
substantial population densities were found to cause severe damage to a wide range of crops and ornamental plants (preferably more succulent and leafy vegetables and plants), and, thus, can be potentially considered as new agricultural and garden (both urban and suburban) pests of serious concern.

The above mentioned species, which are considered to be agricultural pests in Egyptian agricultural system, and their distribution are presented in Table 1. Monacha obstructa and Massylaea vermiculata were the most abundant gastropod species recorded in 19 and 10 localities, respectively, out of the twenty-two surveyed ones. Meanwhile, slugs were found to be common in nurseries and in shady spots in conditions of heavy irrigation and humidity.

\section{Terrestrial slugs}

AGRIOLIMACIDAE:

\section{Deroceras laeve (O.F. Müller, 1774) (Figure 1).}

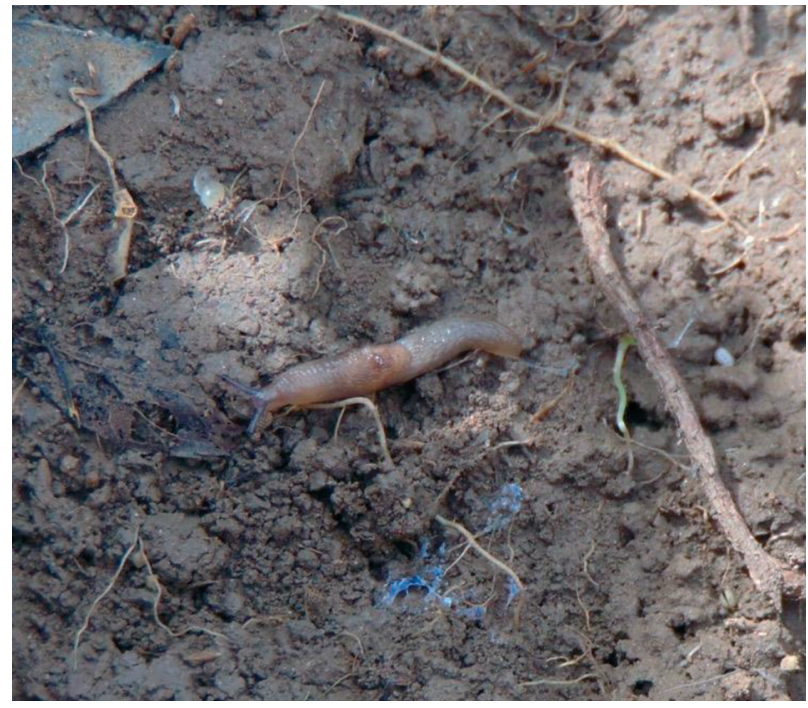

Figure 1. Deroceras laeve (O. F. Müller, 1774) found in an ornamental plant nursery near the road leading to Ashmon, Monufeia. The number of slugs exceeded 10 individuals per $50 \times 50 \mathrm{~cm}^{2}$ area.

Original distribution: Native throughout Europe into the Arctic (Rowson et al. 2014) and also native to Asia and North America (Wiktor 2000; Grimm et al. 2010).

Introduced to: Introduced worldwide.

This ubiquitous species, which is probably the most common invasive gastropod in the world, has been widely spread by human activity for centuries. Although native to temperate climates, it has successfully adapted to subtropical and tropical environments. It is often abundant in greenhouses, where it might damage various fruits and plants (Rowson et al. 2014). Godan (1983) noted that D. laeve attacks Phaseolus beans and Pisa peas as well as various flower species.

This species is reported as a pest of floriculture and is often abundant in greenhouses, both heated and unheated, where it might damage fruits and tender parts of plants (Barker 1999; South 1992; Wiktor 2000). As shown in Table 1, this species is mainly recorded in nurseries and gardens in the governorates of Cairo and Giza.

This species has been previously found under different ornamental plant species including aluminum plant Pilea cadierier L., Parlour palm Chamaedorea elegans L., rose-scented pelargonium gravealens L'Heritier, night blooming cestrum noctumum L., Peppermint Mentha piperita L., garden geranium Pelargonium hortorum Bailey, wild wormwood Artemisia vulgaris L., river spiderwort Tradescantia fluminensis Vell., velvet centaurea Centaurea cineraria L., ficus trees Ficus nitida L. and Ficus benjamina L. from some nurseries located in the Cairo governorate (Mohamed and Ali 2011).

Description: the slug is up to $15-25 \mathrm{~mm}$ in length with a short keel. The mantle has fewer and coarser ridges. The tail is almost of the same length as the mantle, the mucus is colorless (Rowson et al. 2014).

\section{LIMACIDAE:}

\section{Ambigolimax valentianus (d'A. de Férussac, 1821)}

Original distribution: The Iberian Peninsula (WelterSchultes 2012), reported from Valencia, eastern Spain (Rowson et al. 2014).

Introduced to: Widely distributed throughout warmer parts of the world and, also, in greenhouses in temperate climates. This species is known as a greenhouse slug or a three-band garden slug. It is spreading throughout northern Europe outdoors and indoors, and is also widespread across southern and western Britain and Ireland (Rowson et al. 2014). It has been recorded in mountain forests of cedar and cork oak of Algeria at an altitude up to $1700 \mathrm{~m}$ (Wiktor 1983).

The species is widely introduced to most parts of Europe (Kerney et al. 1983; South 1992) and worldwide (Herbert 1997; Barker 1999; Wiktor et al. 2000). The species first recorded in Serbia in 2010 (Stojnić et al. 2011) and in Turkey in 2017 is distributed in the Northern Anatolia Region (Ekin and Şeşen 2018). The species, which is mainly established in China and is likely to spread through Asia, is mainly recorded in Chaina (Wiktor et al. 2000). It was formerly known as Lehmannia valentiana. Following the example of Rowson et al. 2014, we have attributed it to Ambigolimax.

A. valentianus prefers moist and shady locations with lots of vegetation, inside bushes and herbs, along stream banks, under moist stones and fallen logs (Stojnić et al. 2011). 
Table 1. The list of sampled terrestrial gastropod species in alphabetical order and their sampling localities in the governorates of Cairo and Giza and their surrounding areas (Twenty-two infested locations out of the thirty-four locations studied).

\begin{tabular}{|c|c|c|c|c|}
\hline & Terrestrial gastropod & $\begin{array}{c}\text { Population } \\
\text { density }\end{array}$ & Location name & $\begin{array}{l}\text { Geographical } \\
\text { co-ordinates }\end{array}$ \\
\hline 1 & \multirow[t]{2}{*}{ Ambigolimax valentianus } & $* *$ & Faculty of Agriculture, Cairo University (Nursery 4), Giza & $\begin{array}{l}30^{\circ} 01.140^{\prime \prime} \mathrm{N} \\
31^{\circ} 12.486^{\prime} \mathrm{E}\end{array}$ \\
\hline & & $* *$ & $\begin{array}{l}\text { The Marriott Hotel garden, El Gezira Street, El Zamalek district on } \\
\text { Gezira Island, Cairo }\end{array}$ & $\begin{array}{l}30^{\circ} 03.456^{\prime} \mathrm{N} \\
31^{\circ} 13.468^{\prime} \mathrm{E}\end{array}$ \\
\hline 2 & Allopeas gracile & * & Faculty of Agriculture, Cairo University (Nursery 1), Giza & $\begin{array}{l}30^{\circ} 01.102^{\prime} \mathrm{N} \\
31^{\circ} 12.481^{\prime} \mathrm{E}\end{array}$ \\
\hline \multirow[t]{4}{*}{3} & \multirow[t]{4}{*}{ Cochlicella acuta } & $* * *$ & $\begin{array}{l}\text { Private property farm, } \\
\text { Kerdasa, Giza }\end{array}$ & $\begin{array}{l}30^{\circ} 03.488^{\prime} \mathrm{N} \\
31^{\circ} 05.955^{\prime} \mathrm{E}\end{array}$ \\
\hline & & * & Faculty of Agriculture, Cairo University (Nursery 1), Giza & $\begin{array}{l}30^{\circ} 01.102^{\prime} \mathrm{N} \\
31^{\circ} 12.481^{\prime} \mathrm{E}\end{array}$ \\
\hline & & $* * *$ & $\begin{array}{l}\text { Agricultural Horticulture Research Institute El Qanater El Khayreya } \\
\text { (Tropical Fruit Research Station), Qalyubia }\end{array}$ & $\begin{array}{l}30^{\circ} 11.601^{\prime} \mathrm{N} \\
31^{\circ} 06.693^{\prime} \mathrm{E}\end{array}$ \\
\hline & & $* *$ & $\begin{array}{l}\text { The Marriott Hotel garden, El Gezira Street, El Zamalek district on } \\
\text { Gezira Island, Cairo }\end{array}$ & $\begin{array}{l}30^{\circ} 03.456^{\prime} \mathrm{N} \\
31^{\circ} 13.468^{\prime} \mathrm{E}\end{array}$ \\
\hline \multirow[t]{6}{*}{4} & \multirow[t]{6}{*}{ Deroceras laeve } & $*$ & Ornamental plant nursery in El Mansoria, Giza & $\begin{array}{l}30^{\circ} 06.235^{\prime} \mathrm{N} \\
31^{\circ} 07.141^{\prime} \mathrm{E}\end{array}$ \\
\hline & & $*$ & Faculty of Agriculture, Cairo University (Nursery 1), Giza & $\begin{array}{l}30^{\circ} 01.102^{\prime} \mathrm{N} \\
31^{\circ} 12.481^{\prime} \mathrm{E}\end{array}$ \\
\hline & & $* *$ & $\begin{array}{l}\text { Ornamental plant nursery close to Tropical Fruit Research Station, } \\
\text { Qalyubia }\end{array}$ & $\begin{array}{l}30^{\circ} 11.636^{\prime} \mathrm{N} \\
31^{\circ} 06.958^{\prime} \mathrm{E}\end{array}$ \\
\hline & & $* *$ & El Ahaly village in El Qanater El Khayreya, Qalyubia & $\begin{array}{l}30^{\circ} 11.878^{\prime} \mathrm{N} \\
31^{\circ} 06.732^{\prime} \mathrm{E}\end{array}$ \\
\hline & & $* * *$ & $\begin{array}{l}\text { Ornamental plant nursery near the road leading to Ashmon close to } \\
\text { Ezbet Abo Seif, Monufeia }\end{array}$ & $\begin{array}{l}30^{\circ} 14.040^{\prime} \mathrm{N} \\
31^{\circ} 05.215^{\prime} \mathrm{E}\end{array}$ \\
\hline & & $* *$ & $\begin{array}{l}\text { The Marriott Hotel garden, El Gezira Street, El Zamalek district on } \\
\text { Gezira Island, Cairo }\end{array}$ & $\begin{array}{l}30^{\circ} 03.456^{\prime} \mathrm{N} \\
31^{\circ} 13.468^{\prime} \mathrm{E}\end{array}$ \\
\hline 5 & Laevicaulis alte & $* * *$ & $\begin{array}{l}\text { Abo Rawash, El Saliba district, near the road leading to El } \\
\text { Mansouria, Giza }\end{array}$ & $\begin{array}{l}30^{\circ} 05.975^{\prime} \mathrm{N} \\
31^{\circ} 04.717^{\prime} \mathrm{E}\end{array}$ \\
\hline \multirow[t]{2}{*}{6} & \multirow[t]{2}{*}{ Limacus flavus } & $*$ & Faculty of Agriculture, Cairo University (Nursery 4), Giza & $\begin{array}{l}30^{\circ} 01.140^{\prime} \mathrm{N} \\
31^{\circ} 12.486^{\prime} \mathrm{E}\end{array}$ \\
\hline & & $* * *$ & $\begin{array}{l}\text { The Marriott Hotel garden, El Gezira Street, El Zamalek district on } \\
\text { Gezira Island, Cairo }\end{array}$ & $\begin{array}{l}30^{\circ} 03.456^{\prime} \mathrm{N} \\
31^{\circ} 13.468^{\prime} \mathrm{E}\end{array}$ \\
\hline \multirow[t]{10}{*}{7} & \multirow[t]{10}{*}{ Massylaea vermiculata } & $* *$ & Private property nursery, Kerdasa, Giza & $\begin{array}{l}30^{\circ} 03.248^{\prime} \mathrm{N} \\
31^{\circ} 05.891^{\prime} \mathrm{E}\end{array}$ \\
\hline & & ** & Ornamental plants nursery in El Mansoria, Giza & $\begin{array}{l}30^{\circ} 06.235^{\prime} \mathrm{N} \\
31^{\circ} 07.141^{\prime} \mathrm{E}\end{array}$ \\
\hline & & $* *$ & Faculty of Agriculture, Cairo University, Giza & $\begin{array}{l}30^{\circ} 01.119^{\prime} \mathrm{N} \\
31^{\circ} 12.674^{\prime} \mathrm{E}\end{array}$ \\
\hline & & $* * *$ & $\begin{array}{l}\text { Agricultural Horticulture Research Institute El Qanater El Khayreya } \\
\text { (Tropical Fruit Research Station), Qalyubia }\end{array}$ & $\begin{array}{l}30^{\circ} 11.601^{\prime} \mathrm{N} \\
31^{\circ} 06.693^{\prime} \mathrm{E}\end{array}$ \\
\hline & & $* * *$ & $\begin{array}{l}\text { Ornamental plants nursery close to Tropical Fruit Research Station, } \\
\text { Qalyubia }\end{array}$ & $\begin{array}{l}30^{\circ} 11.636^{\prime} \mathrm{N} \\
31^{\circ} 06.958^{\prime} \mathrm{E}\end{array}$ \\
\hline & & $* *$ & El Ahaly village in El Qanater El Khayreya, Qalyubia & $\begin{array}{l}30^{\circ} 11.878^{\prime} \mathrm{N} \\
31^{\circ} 06.732^{\prime} \mathrm{E}\end{array}$ \\
\hline & & $*$ & $\begin{array}{l}\text { El Bagor, Ezbet Shahin } \\
\text { Monufeia }\end{array}$ & $\begin{array}{l}30^{\circ} 13.588^{\prime} \mathrm{N} \\
31^{\circ} 05.402^{\prime} \mathrm{E}\end{array}$ \\
\hline & & $* * *$ & $\begin{array}{l}\text { Ornamental plant nursery near the road leading to Ashmon close to } \\
\text { Ezbet Abo Seif, Monufeia }\end{array}$ & $\begin{array}{l}30^{\circ} 14.040^{\prime} \mathrm{N} \\
31^{\circ} 05.215^{\prime} \mathrm{E}\end{array}$ \\
\hline & & $* * *$ & $\begin{array}{l}\text { The Marriott Hotel garden, El Gezira Street, El Zamalek district on } \\
\text { Gezira Island, Cairo }\end{array}$ & $\begin{array}{l}30^{\circ} 03.456^{\prime} \mathrm{N} \\
31^{\circ} 13.468^{\prime} \mathrm{E}\end{array}$ \\
\hline & & $* *$ & $\begin{array}{l}\text { Abo Rawash, El Saliba district near the road leading to El Mansouria, } \\
\text { Giza }\end{array}$ & $\begin{array}{l}30^{\circ} 05.975^{\prime} \mathrm{N} \\
31^{\circ} 04.717^{\prime} \mathrm{E}\end{array}$ \\
\hline
\end{tabular}




\begin{tabular}{|c|c|c|c|c|}
\hline & Terrestrial gastropod & $\begin{array}{l}\text { Population } \\
\text { density }\end{array}$ & Location name & $\begin{array}{l}\text { Geographical } \\
\text { co-ordinates }\end{array}$ \\
\hline \multirow[t]{19}{*}{8} & \multirow[t]{19}{*}{ Monacha obstructa } & $*$ & Shoubra El Kheima, Qalyub, Qalyubia & $\begin{array}{l}30^{\circ} 10.464^{\prime} \mathrm{N} \\
31^{\circ} 13.876^{\prime} \mathrm{E}\end{array}$ \\
\hline & & $* *$ & Shoubra El Kheima, Qalyub, Qalyubia & $\begin{array}{l}30^{\circ} 10.569^{\prime} \mathrm{N} \\
31^{\circ} 13.917^{\prime} \mathrm{E}\end{array}$ \\
\hline & & * & Shoubra El Kheima, Qalyub, Qalyubia & $\begin{array}{l}30^{\circ} 10.605^{\prime} \mathrm{N} \\
31^{\circ} 14.068^{\prime} \mathrm{E}\end{array}$ \\
\hline & & $*$ & $\begin{array}{l}\text { Private property nursery, } \\
\text { Kerdasa, Giza }\end{array}$ & $\begin{array}{l}30^{\circ} 03.248^{\prime} \mathrm{N} \\
31^{\circ} 05.891^{\prime} \mathrm{E}\end{array}$ \\
\hline & & $*$ & $\begin{array}{l}\text { Private property farm, } \\
\text { Kerdasa, Giza }\end{array}$ & $\begin{array}{l}30^{\circ} 03.488^{\prime} \mathrm{N} \\
31^{\circ} 05.955^{\prime} \mathrm{E}\end{array}$ \\
\hline & & * & Ornamental plants nursery in El Mansoria, Giza & $\begin{array}{l}30^{\circ} 06.235^{\prime} \mathrm{N} \\
31^{\circ} 07.141^{\prime} \mathrm{E}\end{array}$ \\
\hline & & $* *$ & Faculty of Agriculture, Cairo University, Giza & $\begin{array}{l}30^{\circ} 01.119^{\prime} \mathrm{N} \\
31^{\circ} 12.674^{\prime} \mathrm{E}\end{array}$ \\
\hline & & * & Faculty of Agriculture, Cairo University (Nursery 1), Giza & $\begin{array}{l}30^{\circ} 01.102^{\prime} \mathrm{N} \\
31^{\circ} 12.481^{\prime} \mathrm{E}\end{array}$ \\
\hline & & $* * *$ & $\begin{array}{l}\text { "Kale'et El Marazik" (El Marazik Castle) Manshiet Dahshour, } \\
\text { Giza }\end{array}$ & $\begin{array}{l}29^{\circ} 47.734^{\prime} \mathrm{N} \\
31^{\circ} 15.268^{\prime} \mathrm{E}\end{array}$ \\
\hline & & $* *$ & El Ayat, Giza & $\begin{array}{l}29^{\circ} 48.111^{\prime} \mathrm{N} \\
31^{\circ} 16.679^{\prime} \mathrm{E}\end{array}$ \\
\hline & & $* *$ & Small village, El Hawmdeia, Giza & $\begin{array}{l}29^{\circ} 53.829^{\prime} \mathrm{N} \\
31^{\circ} 15.060^{\prime} \mathrm{E}\end{array}$ \\
\hline & & $* * *$ & $\begin{array}{l}\text { Abo Seir Village, El Badrashin, near the road leading to the Faculty } \\
\text { of Agriculture, Giza }\end{array}$ & $\begin{array}{l}29^{\circ} 53.902^{\prime} \mathrm{N} \\
31^{\circ} 13.612^{\prime} \mathrm{E}\end{array}$ \\
\hline & & $* *$ & Near the road leading to El Qanater El Khayreya, Qalyubia & $\begin{array}{l}30^{\circ} 01.140^{\prime} \mathrm{N} \\
31^{\circ} 12.486^{\prime} \mathrm{E}\end{array}$ \\
\hline & & $*$ & Gezeret El Kertieen, near the road leading to El Glatma, Giza & $\begin{array}{l}30^{\circ} 09.464^{\prime} \mathrm{N} \\
31^{\circ} 08.165^{\prime} \mathrm{E}\end{array}$ \\
\hline & & $* * *$ & $\begin{array}{l}\text { Agricultural Horticulture Research Institute El Qanater El Khayreya } \\
\text { (Tropical Fruit Research Station), Qalyubia }\end{array}$ & $\begin{array}{l}30^{\circ} 11.601^{\prime} \mathrm{N} \\
31^{\circ} 06.693^{\prime} \mathrm{E}\end{array}$ \\
\hline & & $* * *$ & $\begin{array}{l}\text { Ornamental plants nursery close to Tropical Fruit Research Station, } \\
\text { Qalyubia }\end{array}$ & $\begin{array}{l}30^{\circ} 11.636^{\prime} \mathrm{N} \\
31^{\circ} 06.958^{\prime} \mathrm{E}\end{array}$ \\
\hline & & $* *$ & El Ahaly village in El Qanater El Khayreya, Qalyubia & $\begin{array}{l}30^{\circ} 11.878^{\prime} \mathrm{N} \\
31^{\circ} 06.732^{\prime} \mathrm{E}\end{array}$ \\
\hline & & * & El Bagor, Ezbet Shahin, Monufeia & $\begin{array}{l}30^{\circ} 13.588^{\prime} \mathrm{N} \\
31^{\circ} 05.402^{\prime} \mathrm{E}\end{array}$ \\
\hline & & $* * *$ & $\begin{array}{l}\text { Ornamental plant nursery near the road leading to Ashmon close to } \\
\text { Ezbet Abo Seif, Monufeia }\end{array}$ & $\begin{array}{l}30^{\circ} 14.040^{\prime} \mathrm{N} \\
31^{\circ} 05.215^{\prime} \mathrm{E}\end{array}$ \\
\hline 9 & Oxychilus cf. cellarius & * & $\begin{array}{l}\text { The Marriott Hotel garden, El Gezira Street, El Zamalek district on } \\
\text { Gezira Island, Cairo }\end{array}$ & $\begin{array}{l}30^{\circ} 03.456^{\prime} \mathrm{N} \\
31^{\circ} 13.468^{\prime} \mathrm{E}\end{array}$ \\
\hline \multirow[t]{3}{*}{10} & \multirow[t]{3}{*}{ Theba pisana } & $*$ & $\begin{array}{l}\text { Ornamental plants nursery close to Tropical Fruit Research Station, } \\
\text { Qalyubia }\end{array}$ & $\begin{array}{l}30^{\circ} 11.636^{\prime} \mathrm{N} \\
31^{\circ} 06.958^{\prime} \mathrm{E}\end{array}$ \\
\hline & & $*$ & El Ahaly village in El Qanater El Khayreya, Qalyubia & $\begin{array}{l}30^{\circ} 11.878^{\prime} \mathrm{N} \\
31^{\circ} 06.732^{\prime} \mathrm{E}\end{array}$ \\
\hline & & $*$ & $\begin{array}{l}\text { Abo Rawash, El Saliba district near the road leading to El Mansouria, } \\
\text { Giza }\end{array}$ & $\begin{array}{l}30^{\circ} 05.975^{\prime} \mathrm{N} \\
31^{\circ} 04.717^{\prime} \mathrm{E}\end{array}$ \\
\hline 11 & Polygyra cereolus & $* * *$ & $\begin{array}{l}\text { The Marriott Hotel garden, El Gezira Street, El Zamalek district on } \\
\text { Gezira Island, Cairo }\end{array}$ & $\begin{array}{l}30^{\circ} 03.456^{\prime} \mathrm{N} \\
31^{\circ} 13.468^{\prime} \mathrm{E}\end{array}$ \\
\hline 12 & Zonitoides arboreus & $*$ & Faculty of Agriculture, Cairo University (Nursery 1), Giza & $\begin{array}{l}30^{\circ} 01.102^{\prime} \mathrm{N} \\
31^{\circ} 12.481^{\prime} \mathrm{E}\end{array}$ \\
\hline
\end{tabular}

Notes: $(*)=$ The number of snails varies from 3 to 5 individuals per $50 \times 50 \mathrm{~cm}^{2}$ area; $(* *)=$ The number of snails varies from 6 to 10 individuals per $50 \times 50 \mathrm{~cm}^{2}$ area; $(* * *)=$ The number of snails per $50 \times 50 \mathrm{~cm}^{2}$ area exceeds 10 individuals. 
In this study, this species was found at one location of the Faculty of Agriculture, Cairo University (Nursery 4) $\left(30^{\circ} 01.140^{\prime} \mathrm{N} 31^{\circ} 12.486^{\prime} \mathrm{E}\right)$ feeding on mango seedlings and in the shade of plant pots. In green houses, it can be a serious pest of orchids and other varieties of roses (South 1992).

Description: The body color is variable from cream to brownish, the body length of a medium sized slug ranges from 50 to $80 \mathrm{~mm}$ (Rowson et al. 2014). There are at least two longitudinal stripes on the mantle (except in unicolor forms) and along the body to the tail; the sole is lighter in the middle. The mucus is colorless and watery (Stojnić et al. 2011).

\section{Limacus flavus (Linnaeus, 1758)}

Original distribution: Possibly the Mediterranean region, western and central Europe (Welter-Schultes 2012).

Introduced to: South Africa (Herbert 2010); Zimbabwe (Van Bruggen 1981); Saint Helena (Crowley 1978); British Columbia, Canada (Forsyth 1999); throughout most of the USA (Pilsbry 1948); Victoria, New South Wales and Tasmania (Smith and Kershaw 1979); and New Zealand (Barker 1999). It has been reported as a pest of various flower species in greenhouses (Godan 1983). It is common in gardens and nurseries of ornamental plants (Ali 2011; Mohamed and Ali 2013).

Description: it is a medium-size to large-size slug species up to $80-130 \mathrm{~mm}$ in body length with a short and unclear keel. The body is characterized by yellow-brown or yellow-green blotches with a central yellow stripe along the back to the tail tip (Rowson et al. 2014).

\section{VERONICELLIDAE:}

Laevicaulis alte (d'A. de Férussac, 1822) (Figure 2).

Original distribution: This species is native to southern

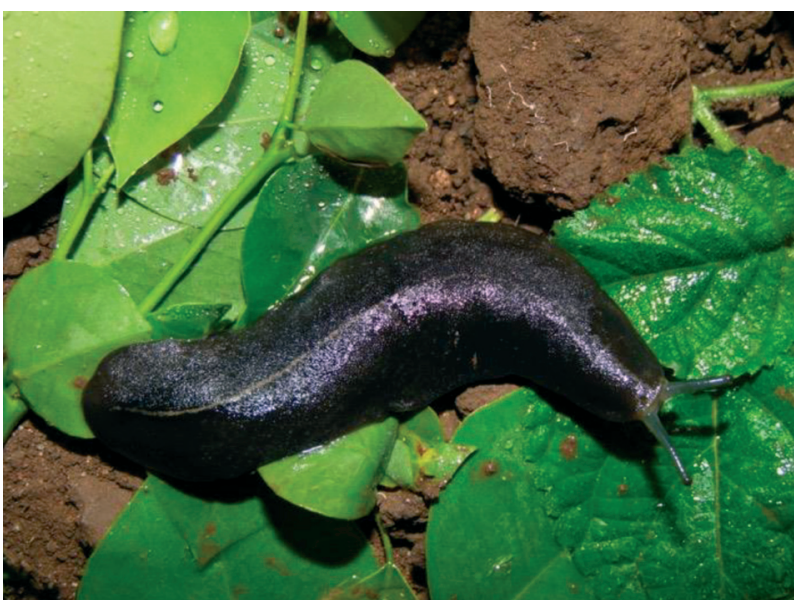

and central Africa (Forcart 1953; Cowie 2000), is established in southern and southeastern Asia and is recorded in the Pacific Basin and the Hawaiian Islands (Cowie et al. 2009; Robinson and Hollingsworth 2009). It is considered as a national quarantine pest of top significance in the USA with adverse effects on agriculture, human health and natural ecosystems (Cowie et al. 2009). The species has been recorded in India as well (Ray and Mukherjee 1963).

Introduced to: India, where it is considered to be a very serious agricultural pest with increasingly high rates of infestation (Raut and Mandal 1984; Raut and Panigrahi 1989; Das and Parida 2015; Bhavare and Magare 2017), Sri Lanka (Kumburegama and Ranawana 2001; Marambe et al. 2011), Australia (Smith and Dartnall 1976), Fiji (Brodie and Barker 2012), Samoa and American Samoa (Gomes and Thomé 2004; Robinson and Hollingsworth 2009), Pratas Islands, Taiwan (Wu et al. 2007) as well to Qatar (El-Alfy et al. 1994) and Saudi Arabia (Neubert 1998). This species has been introduced to many regions (Herbert and Kilburn 2004).

In the Egyptian agricultural ecosystem, this species was first recorded in October 2018 in a nursery of ornamental plants and in a garden in Abo Rawash, in the El Saliba district near the road leading to the El Mansouria village, Giza governorate, at the coordinates $30^{\circ} 05.975^{\prime}$ $\mathrm{N} 31^{\circ} 04.717^{\prime} \mathrm{E}$, on seedlings, under plant pots and old leaves in nurseries and green houses, where it is more shady and humid, avoiding direct sunlight. Slugs of this species were found aggregated in big numbers on numerous ornamental plants attempting to hide in the shade of plant pots, close to the ground surface, where more humid conditions protect them from direct sunlight.

The other two terrestrial snail species found at the same location, were Massylaea vermiculata and Theba pisana.

Laevicaulis alte was recorded in the field on the following ornamental plants: Nephrolepis spp. Fern (Ne-

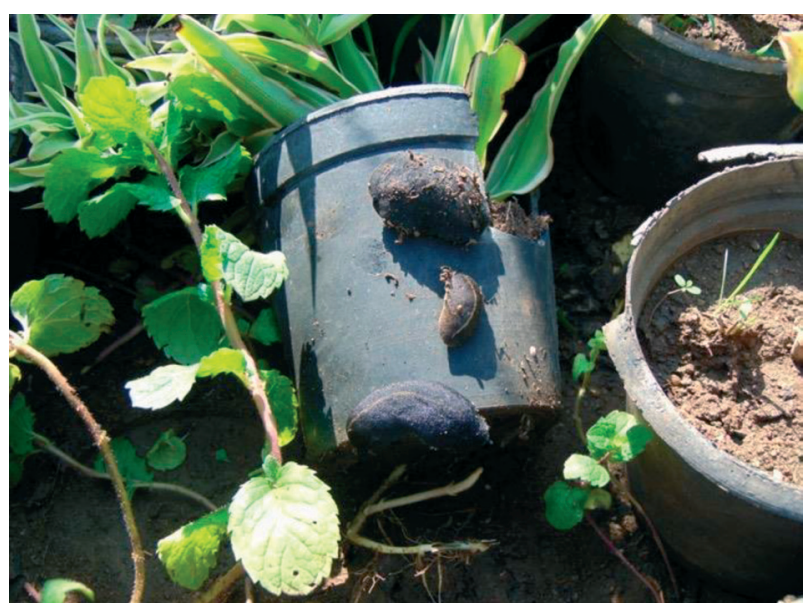

Figure 2. Laevicaulis alte (d'A. de Férussac, 1822) found on ornamental plants in a garden located in Abo Rawash, El Saliba, El Mansouria, Giza governorate. The number of slugs exceeded 10 individuals per $50 \times 50 \mathrm{~cm}^{2}$ area. 
phrolepidaceae), Plectranthus scutellarioides Common coleus (Lamiaceae), Duranta erecta Golden dew-drop (Verbenaceae), Aptenia cordifolia Heartleaf ice plant (Aizoaceae), Kalanchoe marmorata Penwiper plant (Crassulaceae), Aloe nobilis rubble aloe (Asphodelaceae), Tradescantia pallida Purple heart (Commelinaceae), Ruellia brittoniana Britton's wild petunia (Acanthaceae), Senecio mandraliscae Blue Senecio (Asteraceae), Agave americana century plant (Asparagaceae), Crassula ovata jade plant (Crassulaceae), Polianthes tuberosa the tuberose (Asparagaceae), Tradescantia spathacea the boat lily (Commelinaceae) and Mangifera indica mango seedlings (Anacardiaceae) as fruit.

The infested garden and nursery were irrigated almost every day to maintain the level of continuous humidity necessary for slug reproduction and successful completion of their life cycle.

In the future, this gastropod pest is expected to endanger the agricultural ecosystem and cause serious threat to ornamental plants and other field crops.

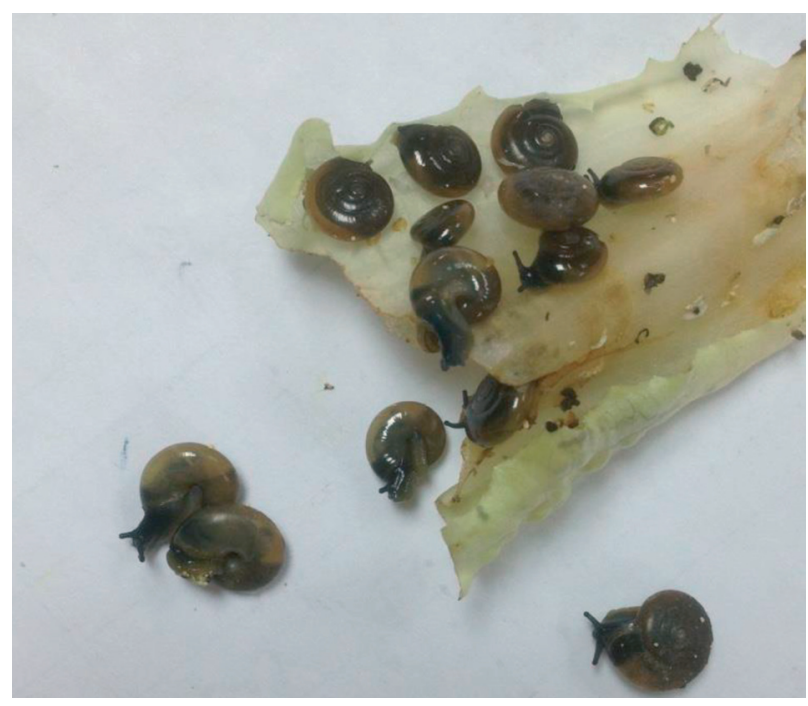

Figure 3. Oxychilus cf. cellarius (O. F. Müller, 1774) found on grass and some ornamental plants in the district of El Zamalek on Gezira Island, the Cairo governorate. The number of snails ranged from 3 to 5 individuals per $50 \times 50 \mathrm{~cm}^{2}$ area.
Description: Laevicaulis alte is an elongated dark-colored slug capable of contracting itself into an oval shape. On its head, the slug has $2-3 \mathrm{~mm}$ long tentacles, rarely extending beyond the edge of the mantle; the slug can retract its head under the mantle. The central keel is beige in color. Adult specimens of this slug have a unique, very narrow foot, which is around 4 or $5 \mathrm{~mm}$ in width. The notum is dark-grey to light yellowish-grey, with darker spots. Hyponotum is lighter than the back, both surfaces are minutely granular (Benthem-Jutting 1952).

The body is usually large reaching up to $10 \mathrm{~cm}$ (Robinson and Hollingsworth 2009) and sometimes up to $12 \mathrm{~cm}$ (Herbert and Kilburn 2004) in length.

\section{Terrestrial snails}

\section{OXYCHILIDAE:}

Oxychilus cf. cellarius (O. F. Müller, 1774) (Figure 3, Figure 4).

\section{Original distribution: Europe.}

Introduced to: Introduced worldwide, i.e. to New Zealand (Spencer et al. 2009), the Czech Republic and Slovakia (Horsák et al. 2010).

As specimens of this species were juvenile and their genitalia were not fully developed, they could be identified to the species level only tentatively. However, as shown in Figure 4a, b, c, the shells are consistent with those of Oxychilus cellarius, which is known as a pest of Phaeseolus beans in gardens and greenhouse environments (Godan 1983). Another species belonging to the genus Oxychilus is Oxychilus alliarius found on navel orange trees, i.e. the most land snail-infested plants in the Berkat-El Sabaa district, Monufia governorate (Mohammed 2015). In the region of Abbes, Alexandria governorate, this species is recorded on grapevines (Eshra 2013).

It is a mesophilic species of woods, rocks, fields, and, occasionally, of gardens and greenhouses, where species rest under rocks, logs, and under bark of fallen trees, or in leaf litter and moss (Kerney et al. 1983).
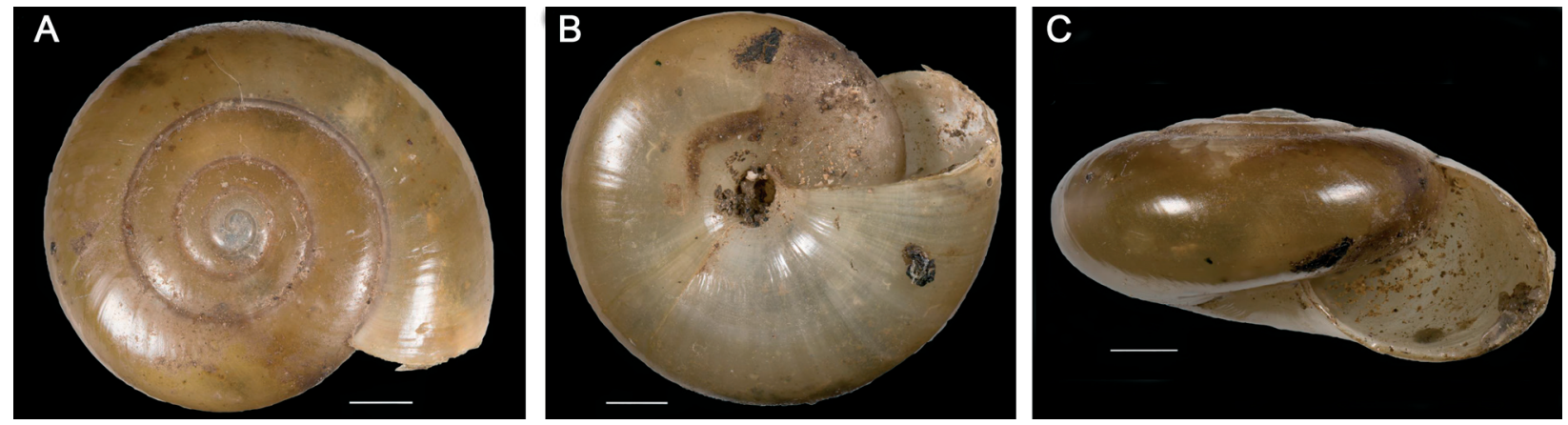

Figure 4. A close-up of the shell of Oxychilus cf. cellarius (O. F. Müller, 1774): dorsal view, ventral view, lateral view (scale: $1 \mathrm{~mm})$. 
The related species Oxychilus alliarius (Oxychilidae) reported as an invasive predator and facultative carnivore species is one of the main causes of the extinction of the rare species Kaala subrutila (Helicarionidae) and Pleuropoma $\mathrm{cf}$. sandwichiensis (Helicinidae) that are native to the Hawaiian Islands (Curry and Yeung 2013).

As an invasive predator species, Oxychilus sp. may be potentially threatening to other native species of gastropods or other beneficial worms in the Egyptian ecosystem in the future.

Description: The shell is medium sized, spire is low, color is greyish yellow and paler below than above, the surface is polished, growth lines are faint, suture may appear channeled, aperture is elliptical (Long 1972). The shell is $9-12 \mathrm{~mm}$ in diameter, very flattened, very pale, transparent, shiny, glossy with $5 \frac{1}{2}$ to 6 whorls. Umbilicus is symmetrical, moderately deep and open (Kerny and Cameron 1979). The body color is usually bluish-grey. As it is usually found dead, it is difficult to identify the species from broken or juvenile shells (Cameron 2003).

\section{HELICIDAE:}

Massylaea vermiculata (O. F. Müller, 1774) (Figure 5).

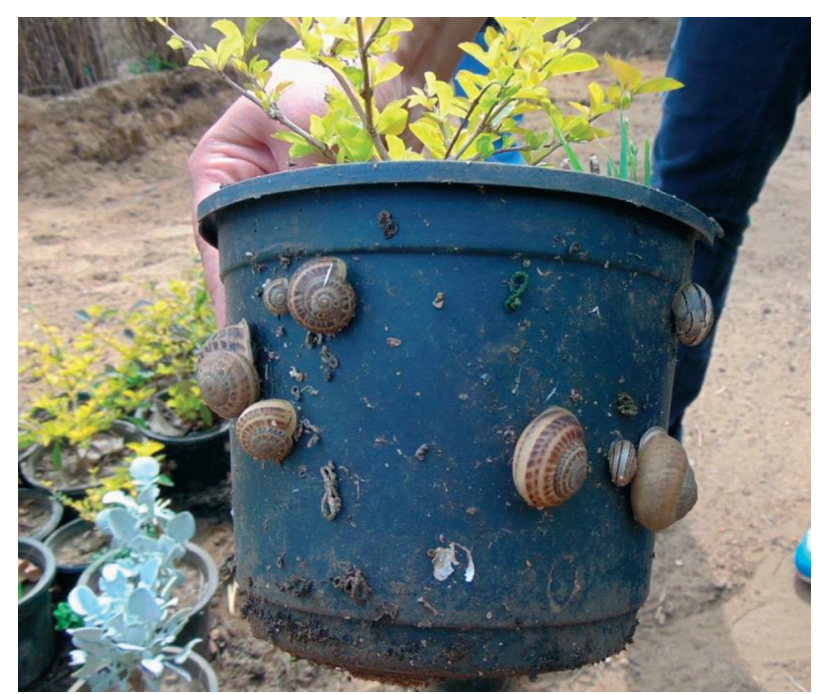

Figure 5. Massylaea vermiculata (O. F. Müller, 1774) found on ornamental plants in a nursery close to the Tropical Fruit Research Station, Qalyubia. The number of snails exceeded 10 individuals per $50 \times 50 \mathrm{~cm}^{2}$ area.

Original distribution: Countries in the Mediterranean Basin (Fechter and Falkner 1990). Massylaea vermiculata has a worldwide distribution due to human activities (Godan 1979).

Introduced to: the Crimean Peninsula (Likhachev and Rammel'mier 1952), the Netherlands (Backhuys 1966), Köln, Germany (Čejka et al. 2014), the Croatian coastal region (Puizina et al. 2013), Belgium (Ronsmans and Van den Neucker 2016), Ashkabad, Turkmenistan
(Muratov 1998), Chiba, Japan (Ueshima et al. 2004; Ueshima 2006), Saudi Arabia (Neubert 1998; Desouky and Busais 2012), Qatar (Al-Khayat 2010), Israel (Mienis 1973), Jordan (Petney and Huset 1992), Kermanshah, Basrah city, Iraq (Al-Khafaji et al. 2016), Iran (Mienis 2002), Georgia (Mumladze and Paposhvili 2016), Texas (Strecker 1935); California, USA (Roth and Sadeghian 2003) reported as a garden pest in Texas and California (Sakovich et al. 1984), New South Wales, Australia (Smith and Kershaw 1979).

Massylaea vermiculata, a dominant helicid land snail in Egypt, formerly known as Eobania vermiculata (Bouaziz-Yahiatene et al. 2017) and reported as a serious pest of Citrus (Hegab et al. 1999; Hashem et al. 1993; El-Deeb et al. 1996b; Mahrous et al. 2002) in the governorates of El Sharkia (Ismail et al. 2017), Beheira, and Alexandria (Eshra 2013).

As reported by Desoky et al. 2015, M. vermiculata, which is found in the districts of Tahta and Sohag, was first recorded in the Sohag governorate during 2014/2015 seasons. Later it was reported to be widely spreading and, during 2016/2017 seasons, it was recorded in six districts already (Desoky 2018).

$M$. vermiculata has been reported to infest navel orange trees, Egyptian clover and wheat in multiple spots in the North-East of Delta governorates such as the Toukh district - Qalyubia governorate, the Zagazig district - Sharkia governorate, the El-Santa district - Gharbia governorate, the Berkat El-Sabaa district-Monufia governorate, the Mit Ghamr district - Dakahlia governorate, the Kafr Saad district-Damietta governorate and the Abou Sultan district - Ismailia governorate (Mohammed 2015).

The species was also recorded in fields of such crops as broad bean Vicia faba, Egyptian clover Trifolium alexandrinum, maize Zae mays, wheat Triticum aestivum, such vegetable crops as cabbage Brassica oleracea var. capitata, lettuce Lactuca sativa, Common bean Phaseolus vulgaris, on such fruit trees as guava Psidium guajava, mango Mangifera indica, and also on some ornamental plants such as Adhatoda Adhatoda vasica, Casuarina Casuarina equisetifolia, Kafor Eucalyptus sp., Cocos Syagrus romanzoffiana, Sansevieria guineensis, Alternanthera amabilis, Chrysanthemum Chrysanthemum induca, Acalypha Acalypha marginata, Indian laurel Ficus nitida (El-Okda 1980; El-Deeb et al. 1996b; Mahrous et al. 2002; Ali 2006). In spite of that, this species is a food item in Turkey (Yildirim et al. 2004) and France (Welter-Schultes 2012).

Description: the shell is $22-30 \mathrm{~mm}$ in diameter, depressed globular in shape, has 5-6 slightly convex whorls. The umbilicus is closed by a reflected lip; the shell is thick, its background is creamy-white, with irregular growth ridges and 5 variable dark brown bands (Kerney and Cameron 1979). 


\section{Theba pisana (O.F. Müller, 1774) (Figure 6).}

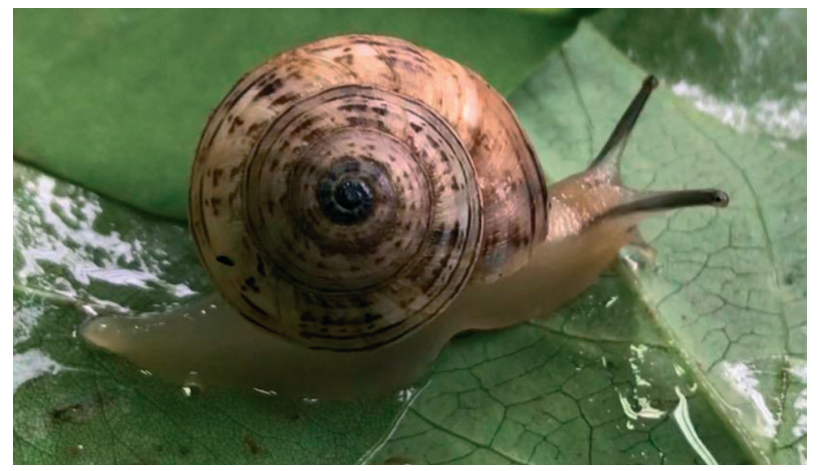

Figure 6. Theba pisana (O.F. Müller, 1774) found on ornamental plants in Abo Rawash, El Saliba district, El Mansouria, Giza governorate. The number of snails ranged from 3 to 5 individuals per $50 \times 50 \mathrm{~cm}^{2}$ area.

Original distribution: Probably from Morocco (Sacchi 1955; Gittenberger and Ripken 1987).

Introduced to: Throughout the Mediterranean Basin; established in numerous European countries such as Britain, France, Belgium, the Netherlands, Ireland and Switzerland (Kerney and Cameron 1979) and also in Australia, South Africa, the Canary Islands, Madeira, Porto Santo, Bermuda, Brazil, Argentina, and in San Diego and Los Angeles Counties, and in California, where it was first reported in 1914 (Hanna 1966). It is considered to be a very serious agricultural pest attacking ornamental plants, fruits, vegetables and herbs.

In Australia, it is a pest of seedling crops including wheat, barley, oil seeds, seed carrots and legume-based pastures (e.g. annual medics, lucerne, clovers), causing severe damage and occasionally total destruction; Theba pisana is also considered to be a minor pest of Citrus orchards, as well as of grapevines in both South Africa and Australia (Sanderson and Sirgel 2002). In South Africa, this species feeds on grapes. Juveniles of this species feed on foliar buds and young leaves, causing stunted growth and decreased yield besides leaving their mucus on developing grapes, which reduces their quality and consumption and, consequently, fruit export markets (Sanderson and Sirgel 2002). Livestock refuse to consume clover or pasture that is heavily contaminated with snail mucus (Kassab and Daoud 1964; El-Okda 1984).

In Egypt, this snail is considered to be a serious pest of Citrus (Hashem and El-Halawany 1996; El-Wakil 1999). In Beheira and Alexandria governorates, it is also recorded on such fruit trees as apple and navel orange trees as well as on ornamental plants including Crinum thaianum, Delonix regia, Ficus elastic, Senecio cineraria, Rosa spp., Gerbera spp. and Acalypha spp. (Eshra 2013).

In Qalyubia, Sharkia, Gharbia, Damietta and Ismailia governorates, this species is reported to attack wheat as a field crop and navel orange, grapevines and mango as fruits (Mohammed 2015). In the Kafr El Sheikh governorate, this pest was found on Lactuca sativa and Brassica oleracea with high infestation rates (Gazzy et al. 2019).

Theba pisana is also reported as one of natural first intermediate hosts to Brachylaima cribbi, a terrestrial trematode of birds and mammals. Sporocyst-infected snails were detected entirely in districts of Victoria up to the west coast of South Australia (Butcher and Grove 2003), as all intermediate host snails had been introduced into Australia from Europe (Butcher and Grove 2001). In addition, the digeneid fluke, Brachylaima sp. is also associated with severe gut disorders in children in South Australia (Baker 2002).

Description: the shell is approximately $15 \mathrm{~mm}$ in diameter with a white background and numerous spiral bands; the lip is not strong, partly covering the tiny umbilicus (Cameron 2003). The shell has from 5 $\frac{1}{2}$ to 6 slightly convex whorls with shallow sutures (Kerney and Cameron 1979).

\section{HYGROMIIDAE}

Monacha obstructa (L. Pfeiffer, 1842) (Figure 7a, b).

Original distribution: Native to the western Palearctic region from Western Europe, the northern Mediterranean Basin and the Middle East to Iran. In Turkey, M. obstructa is known from the west and south coasts and central and south Anatolia (Hausdorf 2000). This species is widespread and common in the Near East of Africa, is recorded in Turkey (Hausdorf 2000; Gümüş and Neubert 2009), Syria, Lebanon (Neubert and Bariche 2013), Israel (Heller 2009), in the Palestinian Territory (Amr et al. 2018), Jordan (Neubert et al. 2015), Saudi Arabia (Neubert 1998), Iraq (Abdul-Sahib 2006), Qatar (Al-Khayat 2010), Iran and Egypt (Hausdorf 2000). The species is found on different ornamental flowers such as Aconitum sp., Artemisia sp., and Eustoma grandiflorum, on herbs as well as on vegetables, i.e. dill Anethum graveolens and beans Phaseolus sp.

M. obstructa is recorded in Beheira and Alexandria governorates on grapevines, navel orange, and apple as fruit trees and some ornamental plants (Eshra 2013). The same species was found to infest navel orange, Egyptian clover, tomato and cabbage (Mohammed 2015) in the Toukh district - the governorate of Qalyubia and in the El-Santa district - the governorate of Gharbia. The species, which was first recorded during 2014/2015 seasons in the districts of Tahta and Dar-El Salam Sohag governorate (Desoky et al. 2015), spread further, and during 2016/2017 seasons, it was recorded in five districts (Desoky 2018). 

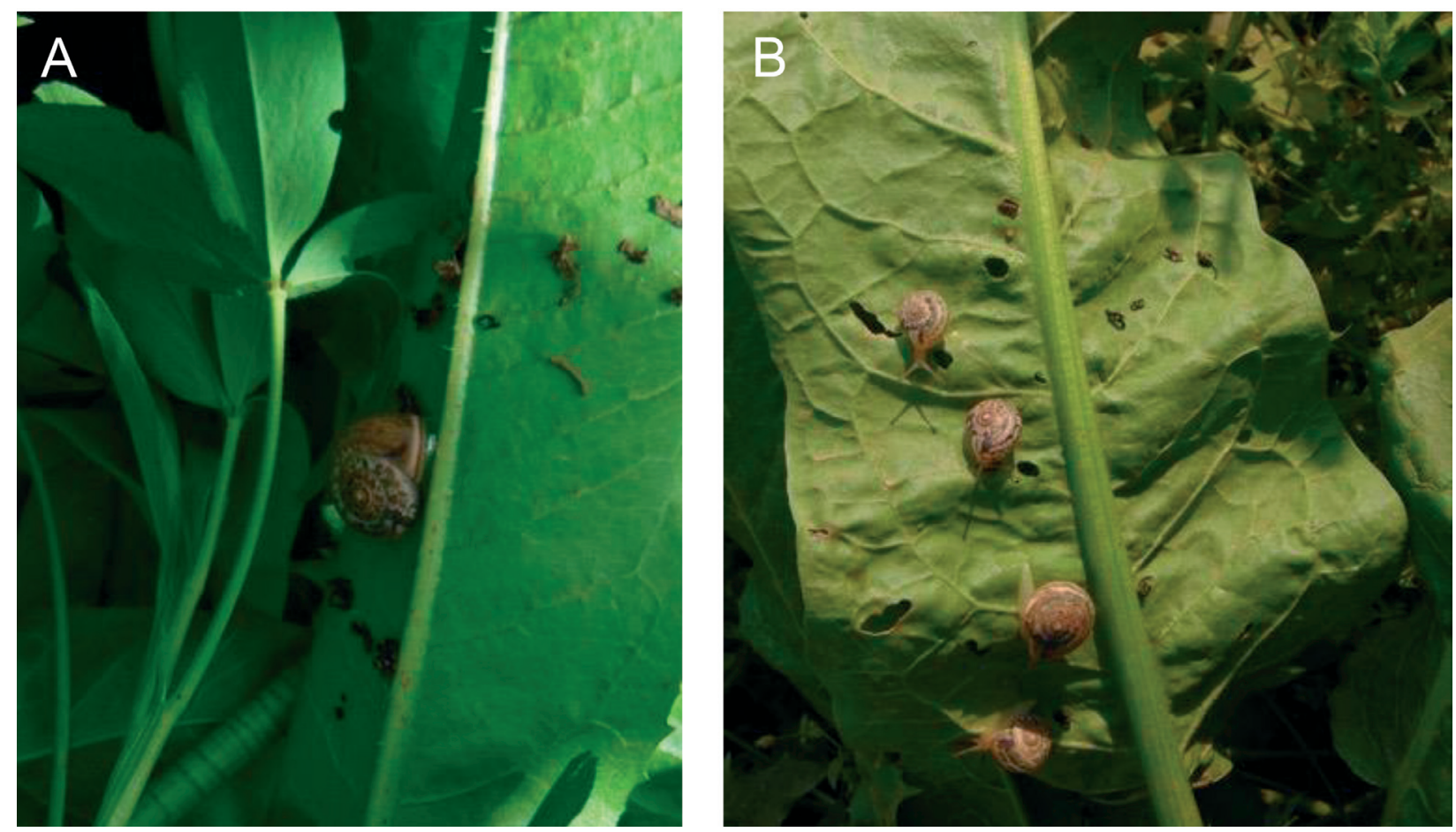

Figure 7. Monacha obstructa (L. Pfeiffer, 1842), a: the species recorded on Chicory Cichorium pumilum, location: Agricultural Horticulture Research Institute El Qanater El Khayreya (Tropical Fruit Research Station), Qalyubia, b: the species recorded on Chard Beta vulgaris subsp. Vulgaris, location: Manshiet Dahshour, Giza governorate. The number of snails on both host plants exceeded 10 individuals per $50 \times 50 \mathrm{~cm}^{2}$ area.

Moreover, in Egypt, M. obstructa was reported as a threat to Citrus (Hashem and El-Halawany 1996) and a vector of the trematode parasite Brachylaima (Rashed 2008). In the present study, the species was found mainly on Egyptian clover Trifolium alexandrinum, in addition to chicory Cichorium pumilum, chard Beta vulgaris subsp. vulgaris, cabbage Brassica oleracea var. capitata, onion Allium cepa, eggplant Solanum melongena in the fields, and in nurseries on some ornamental plants, i.e. cocas palm, Lantana camara, Tradescantia pallida and Chrysanthemum indica. Our study revealed that M. obstructa prefers close-to-ground plant stems and the lower surface of the leaves (Figure 8a, b), in hot noon hours of the day hides inside soil cracks and is found closer to water canals where it is more humid and shady.

Description: The diameter of a medium sized shell ranges from 9.6 to $14.9 \mathrm{~mm}$, the average diameter being $12.00 \mathrm{~mm}$ (Hausdorf 2000). The shell is conical, depressed-globular, with $4 \frac{1}{2}$ to 5 convex whorls, the body whorl is rounded; the aperture is elliptical, the upper insertion of the peristome is slightly descending. The peristome is sharp and hardly expanded; the color of the peristome is brownish with a strong whitish internal rib; the umbilicus is prick-like (Hausdorf 2000; Neubert and Bariche 2013).
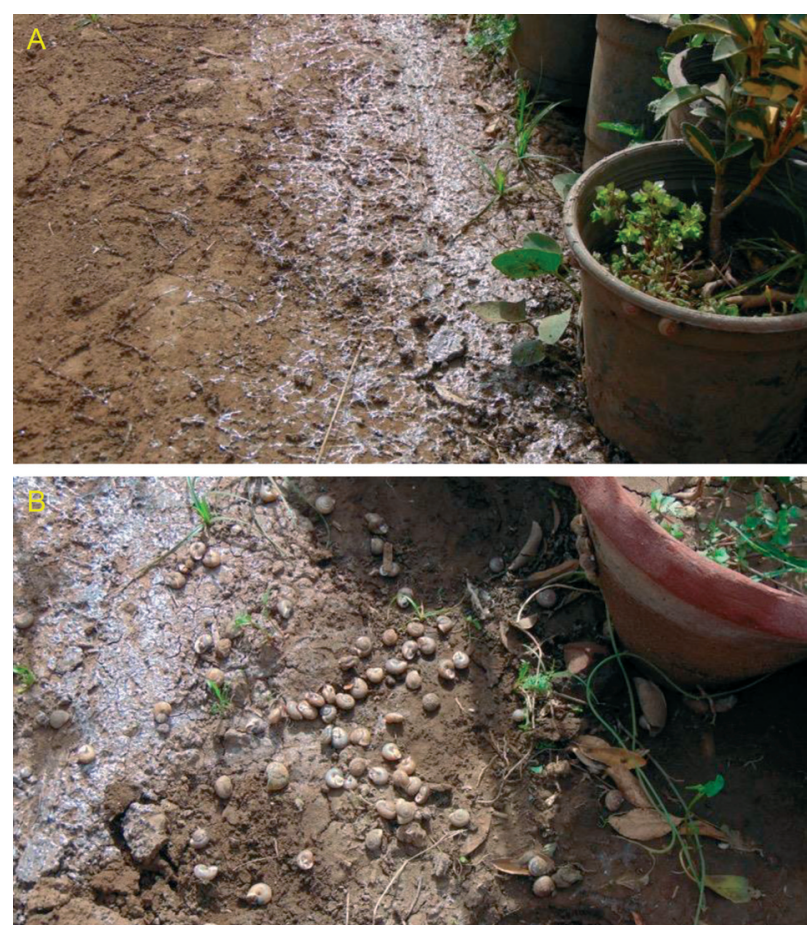

Figure 8. a: Effects of Monacha obstructa (L. Pfeiffer, 1842): Mucus secreted by a large number of snails close to the pot of ornamental plants in an ornamental plant nursery near the road leading to Ashmon, Monufeia, b: A large number of Monacha obstructa snails in the shade of ornamental plant pots at the same location. The number of snails exceeded 10 individuals per $50 \times 50 \mathrm{~cm}^{2}$ area. 


\section{SUBULINIDAE}

\section{Allopeas gracile (Hutton, 1834)}

Original distribution: South America (Auffenberg and Stange 1988).

Introduced to: Dubai, United Arab Emirates (Feulner and Green 2003), Basrah city, Iraq (Naser 2010), India, Sri Lanka, Thailand, Singapore, Vietnam, Republic of China, Philippines, Fiji, Mexico, Central and South America, the Caribbean Basin. In the USA, the species has been reported from South Carolina, Georgia, Florida, Alabama and Louisiana. The species is widespread in tropical and subtropical areas of Asia and Australia as well as in Central and South America. The species is found in temperate areas as a greenhouse inhabitant (Capinera 2017). Allopeas gracile was found under potted ornamentals and young fruit seedlings.

It is known as an almost worldwide-distributed species. The species Allopeas clavulinum was first recorded associated with various ornamental plants in the Mansoura district, Dakahlia governorate (Genena 2003).

Description: The shell is conical, elongated and slender with 6 whorls, maximum length is $7.7 \mathrm{~mm}$ and diameter is $3.0 \mathrm{~mm}$. The whorls are rounded with a deep suture. The aperture is oval and lacks any dentition. The umbilicus is closed (Naser 2010).

\section{GASTRODONTIDAE}

\section{Zonitoides arboreus (Say, 1816)}

Original distribution: North America (Pilsbry 1946; Hubricht 1985).

Introduced to: Iceland, Hungary, Switzerland, the Czech Republic (Dvořák and Kupka 2007), Great Britain, Slovakia, the Pratas Islands, Taiwan (Wu et al. 2007), New Zealand (Spencer et al. 2009). It is known as an "Orchid snail" as it is a common pest of orchids. Snails of the family Zonitidae usually hide under stones and litter by day, eat non-green vegetable matter or small animals (Ellis 1951; Long 1972). Many species of Zonitidae have been introduced to America, Africa and Australasia (Ellis 1951). The species is recorded in greenhouses, gardens and natural habitats, i.e. in woodlands and rotting woods. In this study, this species was recorded in the Faculty of Agriculture, Cairo University (Nursery 1) $\left(30^{\circ} 01.102^{\prime} \mathrm{N} 31^{\circ} 12.481^{\prime} \mathrm{E}\right)$.

Description: Zonitidae are a widespread family of pulmonate land snails, generally small-to medium-sized, 2-20 $\mathrm{mm}$ in diameter with low-spired, thin, transparent to translucent shells (Long 1972). The shell of this species is 5 to $6 \mathrm{~mm}$ in diameter with $4 \frac{1}{2}$ to 5 whorls, thin, glossy and quite fragile, the umbilicus is open (Dourson 2013).

\section{GEOMITRIDAE}

Cochlicella acuta (O. F. Müller, 1774)

Original distribution: The Canary Islands, the northwestern Africa or the Iberian Peninsula (Weltes-Schultes 1998).

Introduced to: Israel (Heller 2009); Jordan (Neubert et al. 2015); Victoria, South Australia (Smith and Kershaw 1979); California, USA (Roth and Hertz 1997). This species is a pest of fodder crops such as lucerne, clover, lupine, sainfoin, and seradella, particularly of their seeds (Godan 1983).

In Egypt, this snail is considered to be a serious pest of Citrus (Hashem and El-Halawany 1996) attacking various plantations in many Egyptian governorates (Kassab and Daoud 1964; El-Okda 1979; El-Deeb et al. 1996a; Eshra 2004). The species is recorded in the governorates of Qalyubia, Gharbia, Monufia, Damietta, and Ismailia. It infests navel orange, Egyptian clover, wheat, maize, potatoes, tomato, lettuce, cabbage (Mohammed 2015). It is reported in King Mariout and Borg El Arab, Alexandria (Ali 2017), is a common species in the Mediterranean region (Kerney and Cameron 1979; USDA 2008) and in the Kafr El Sheikh governorate. It is found on Trifolium alexandrinum and Brassica oleracea in big numbers (Gazzy et al. 2019).

The species was first spotted feeding on Egyptian clover Trifolium alexandrinum and a date palm on a private farm in the Giza governorate $\left(30^{\circ} 03.488^{\prime} \mathrm{N} 31^{\circ} 05.955^{\prime}\right.$ E). It was also found under ornamental plants pots in nurseries of the Faculty of Agriculture $\left(30^{\circ} 01.102^{\prime} \mathrm{N}\right.$ $\left.31^{\circ} 12.481^{\prime} \mathrm{E}\right)$.

Description: the shell is very elongated, cone-shaped, $10-20 \mathrm{~mm}$ in height, $4-7 \mathrm{~mm}$ in diameter; with 8 to 10 convex whorls, with a moderate suture and a minute umbilicus that is obscured by a reflected lip (Kerney and Cameron 1979).

\section{POLYGYRIDAE}

Polygyra cereolus (Megerle von Mühlfeld, 1816) (Figure 9).

Original distribution: Florida, USA (Pilsbry 1940).

Introduced to: such parts of the USA as North Carolina, Virginia and Texas (Cowie 1997), Yucatán, Mexican state (Bequaert and Clench 1936) and Quintana Roo, Mexican state on the Yucatán Peninsula (Rehder 1966), Mexico (Thompson 2008), Puerto Rico, the Greater Antilles (Charles and Lenoble 2020); Bermuda (Bieler and Slapcinsky 2000), the southern United States (Perez 2008), Spain (Navarro-Barrachina et al. 2012); Eastern Province, Saudi Arabia (Neubert 1995, 1998); Abu Dhabi (Neubert, pers. com.), the United Arab Emirates (Feulner et al. 2005), Qatar (Al-Khayat 2010), in 
the Caribbean (Cowie 1996) and O'ahu, the Hawaiian Islands (Cowie 1997). The present study reports this species from the El Zamalek district on Gezira Island, the Cairo governorate for the first time, where it was spotted on ornamental plants.

Description: The discoidal shell is light brown, with radial streaks or spots of gray or pale brown on the base, varying to nearly uniform brown or fawn. The upper surface varies from flat to slightly conoidal, is obliquely, regularly rib-striated; the base nearly flat or slightly concave, with a small vortex-shaped central pit [umbilicus]; the whorls are strongly convex and lightly striated (Figure 10). Periphery is strongly angular to subcarinate. The first whorl emerging from the central pit is prominent, further, the width decreases. The last whorl is somewhat swollen near the aperture, the keel

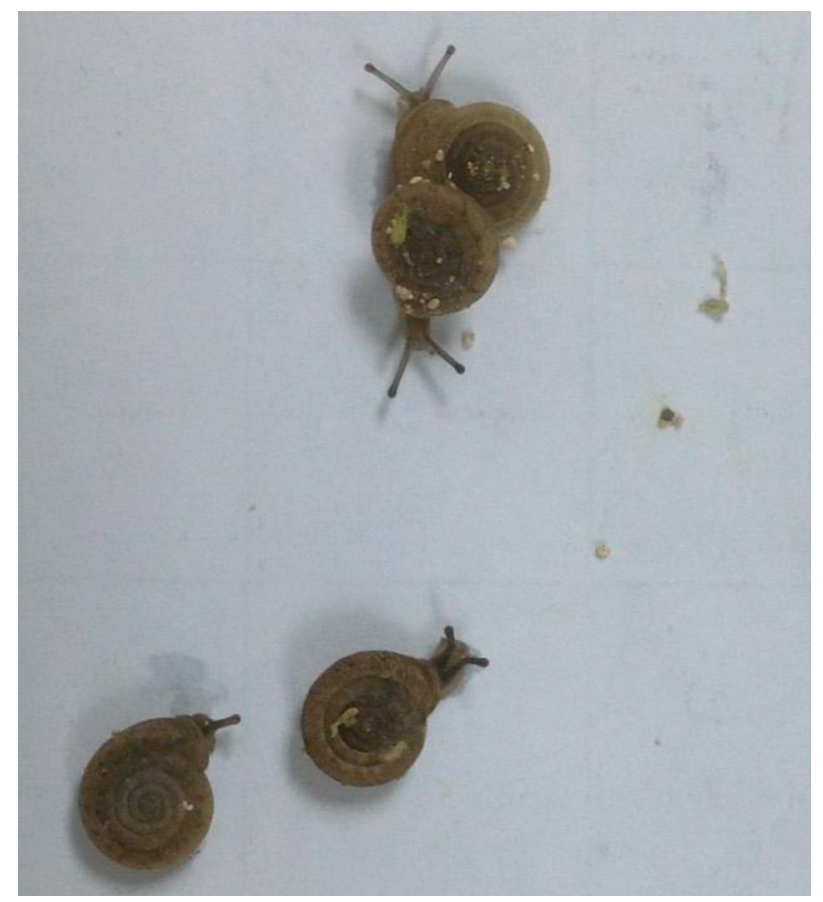

Figure 9. Polygyra cereolus (Megerle von Mühlfeld 1816) recorded in the El Zamalek district on Gezira Island, Cairo. The number of snails exceeded 10 individuals per $50 \times 50$ $\mathrm{cm}^{2}$ area. is weaker or obsolete there. Outer and basal margins of the peristome are reflected and thickened within the parietal, the margin is somewhat raised, free, bearing a short oblique parietal tooth. Within the first half of the last whorl, a narrow white lamina revolves on the parietal wall (Pilsbry 1940).

\section{DISCUSSION}

The present study of gastropods has recorded twelve mollusk species (eight snails and four slugs) newly introduced to the Egyptian malacofauna. They have been added to the list of potential agricultural pests in Egypt with full descriptions of the species and their sampling locations. Ornamental plants in gardens and greenhouses are attacked by different injurious gastropod species, i.e. Massylaea vermiculata, Monacha sp., Theba pisana, and Cochlicella acuta that are common in Northern Egypt (Kassab and Daoud 1964). The mass appearance of these terrestrial gastropods has been gradually recorded in many different spots and locations in Cairo, Giza as well as in the neighboring areas.

El Deeb et al. (1996a) surveyed land mollusk species in various nurseries representing different environmental conditions and ecosystems (Helwan - Masr El Kadima - El Mohandssen - Bolak El Dakrour, Nasr City) distributed in five different regions of the Greater Cairo (Cairo and Giza cities). Six mollusk species, i.e. Massylaea vermiculata, Monacha obstructa, Limax flavus, Cornu aspersum, Xeropicta krynickii, and Cochlicella acuta, were recorded in these five nurseries. The population density of land mollusks was found to vary significantly according to the habitat, plant hosts and weather conditions.

M. vermiculata, Succinea putris and Cepeae nemoralis were determined in Kafr El Sheikh; Monacha cartusiana, M. vermiculata, Cepeae nemoralis, C. acuta, O. alliarius and Helicella sp. in the Damietta governorate; Monacha cartusiana, S. putris, M. vermiculata, C. acuta and C. nemoralis in the Dakahlia governorate (El-Deeb et al. 1996b). Many authors have surveyed land snails
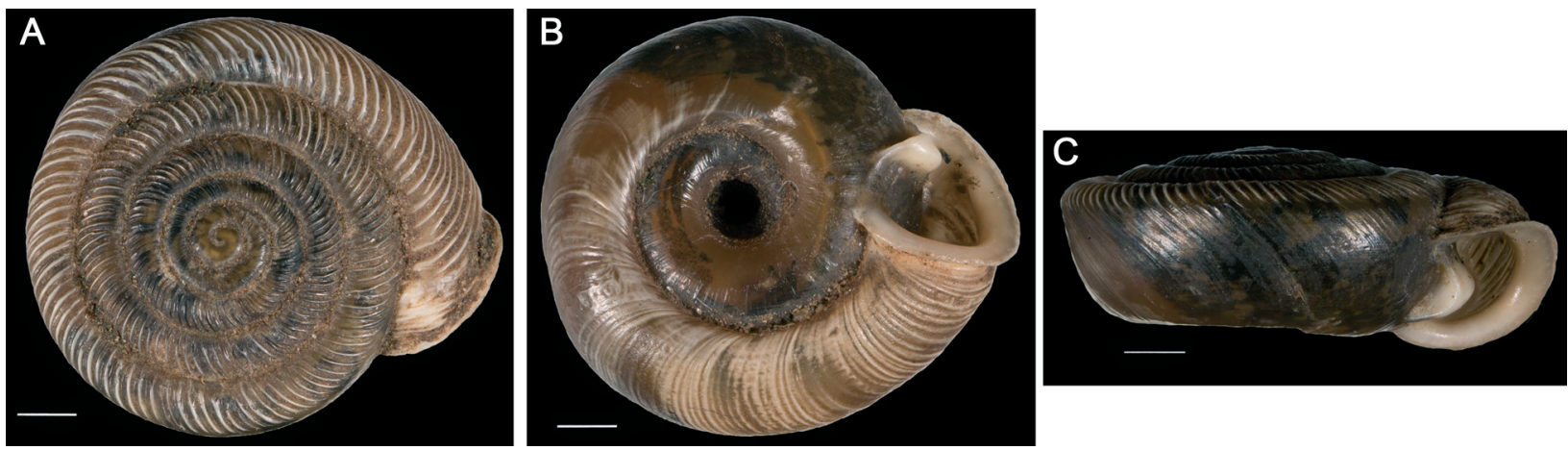

Figure 10. The shell of Polygyra cereolus (Megerle von Mühlfeld, 1816): dorsal view, ventral view and lateral view (scale: $1 \mathrm{~mm})$. 
in the Sharkia governorate and have found Monacha cartusiana, M. vermiculata, C. acuta and X. krynickii attacking field and vegetables crops, fruit trees and ornamental plants in certain localities (Nakhla and Tadros 1995; Ismail 1997; Hegab et al. 1999; Mahrous et al. 2002; Lokma 2007).

Land snails feed on economic and ornamental plants. They consume such edible parts of plants as leaves, fruits, roots, tubers (Bishara et al. 1968; El-Okda 1981) causing serious damage to cereals, maize, Egyptian clover, vegetables, potatoes, lettuce, carrots, cabbage, seeds of oil plants and leaves of ornamental plants, as well as to citrus, peach, and palm trees (El-Deeb et al. 1999; El-Okda 1979; El-Okda 1981; Ismail et al. 2003; Lokma 2007; Shahawy et al. 2008).

In twelve district localities of the Sharkia Governorate (Mahrous et al. 2002), terrestrial snails Monacha cartusiana were mainly recorded on field and vegetable crops, Xeropicta krynickii and Cochlicella acuta on fruit trees, Massylaea vermiculata, which was found to be the most abundant species, on ornamental plants and Succinea sp. The slugs Deroceras reticulatum and D. laeve were first recorded on Egyptian clover in the districts of Meniet El-Kamh and Zagazig, the Sharkia governorate (Lokma 2007).

Massylaea vermiculata, Theba pisana, Xeropicta krynickii, Monacha obstructa and Oxychillus alliarius were recorded on grapevines, navel orange and apple trees, on ornamental plants in the governorates of Alexandria and EL-Beheria. The most abundant species in Alexandria were T. pisana and M. vermiculata (Eshra 2013).

The species Monacha cartusiana, Cochlicella acuta, Succinea putris, Deroceras leave and Deroceras reticulatum were found to infest different crops and host plants in the governorates of Ismailia and Sharkia. Their population density and importance were reported. Our study showed the snail M. cartusiana to be the predominant species on field and vegetable crops (Rady et al. 2014).

Massylaea vermiculata, Theba pisana, Xeropicta krynickii, Cochicella acuta, Monacha cartusiana, Monacha obstructa, Succinea putris, Succinea oblonga, Rumina decollate and Oxychilus alliarius were recorded in field trials in the governorates of North East of Delta, i.e. in Qalyubia, Sharkia, Gharbia, Monufia, Dakahlia, Damietta and Ismailia, on different vegetation including Egyptian clover, wheat, rice, maize; cabbage, lettuce, tomato, potato, grapevines, navel orange, date palm and mango trees (Mohammed 2015).

Our study results suggest that these species have entered gardens with infested seedlings or ornamental plant pots. Based on our study results, we conclude that although not yet reported, these species may have been already introduced to at least a few greenhouses or nurseries in
Egypt, and may spread far and wide in the future. In the first phase, terrestrial mollusks could become established in local areas and, in the absence of biological control agents for land mollusks, get ready for the next phase of transportation to the surrounding clean or reclaimed areas. Snails and slugs are most often translocated to other places through plant nurseries by the movement of plant material (Chichester and Getz 1969).

Having in mind large population densities of these species, their recent distribution in Egypt and their potential distribution in the future, gastropod studies must be continued. The above-mentioned mollusks can cause severe damage to gardens, nurseries and greenhouse plants in Egypt. They are more active in conditions of warm and hot weather, which is typical of Egypt during most of the year. However, the slug Ambigolimax valentianus is unlikely to be active in winter in contrast to the other mollusks recorded during the survey.

The field observations have shown that Egyptian clover Trifolium alexandrinum, chicory Cichorium pumilum and many ornamental plants are sources of nutrition for Monacha obstructa and other species.

It is interesting to note that adult specimens of the Monacha obstructa population from El-Ayat, Giza $\left(29^{\circ} 48.111^{\prime} \mathrm{N} 31^{\circ} 16.679^{\prime} \mathrm{E}\right)$ have a larger diameter shell than specimens of the population from Kerdasa, Giza $\left(30^{\circ} 03.488^{\prime} \mathrm{N} 31^{\circ} 05.955^{\prime} \mathrm{E}\right)$.

As indicated by many malacologists, they identified gastropod species following the methods described by Kassab and Daoud 1964; Bishara et al 1968, or Godan 1983. However, the above mentioned methods alone without the examination of dissected genitalia and shell do not ensure correct species identification.

The gastropod species identification reported in some previous literature sources could be incorrect in many cases, which can be explained by the shortage of clear references, identification keys, the absence of materials and vouchered specimens needed for the verification of species identification. In this respect, a natural history museum housing specimens dating back to the 1990's would be a great support to researchers working in this field.

However, the present study represents just preliminary attempts to record all species of the Egyptian malacofauna and to revise their identification as many species were possibly misidentified due to inadequate descriptions, leading to incomplete surveys of terrestrial snails and slugs.

\section{ACKNOWLEDGEMENTS}

We are grateful to Noha M. Abu-Shady, Assistant Professor at the Department of Zoology and Agricultural Nematology, and Mohamed R. Salama, Lecturer assist- 
ant at the Department of Economic Entomology and Pesticides, Faculty of Agriculture, Cairo University for assistance in collecting /samples/specimens/.

We also thank Asmaa B. El Attar, Associate Professor and Eman Zaky, Assistant Professor at the Ornamental Horticulture department, Faculty of Agriculture, Cairo University for the identification of ornamental plants.

\section{REFERENCES}

Abdul-Sahib, I. M. 2006. A new record of white terrestrial snail Monacha obstructa (Pfeiffer, 1842), (Gastropoda: Pulmonata) from the Iraq marches. Journal of Bashar Researches (Sciences) 32 (3): 70-73.

Abou Senna, F. M., A. H. A. Almaraghy, S. A. A. Ismail, and M. Abed. 2016. Survey and population dynamic of terrestrial gastropods infesting certain crops at Sharkia governorate, Egypt. International Journal of Advanced Research 4 (11): 641-649.

Ali, R. F. 2006. Studies on some snails associated with different crops. M. Sc. Thesis, Faculty of Agriculture, Cairo University, Egypt.

Ali, R. F. 2011. Studies on some gastropods. Ph. D. Thesis, Faculty of Agriculture, Cairo University, Egypt.

Ali, R. F. 2017. Contribution to the Malacofauna of the North coast of Egypt. Folia Malacologica 25 (2): 125-142.

Al-Khafaji, K. K. S., A. M. Abud-Sahab, and M. N. Aziz. 2016. First record of terrestrial snail Eobania vermiculata (O.F. Müller, 1774) (Gastropoda: Helicidae) from Basrah areas, Iraq. Arthropods 5 (3): 125-129.

Al-Khayat, J. 2010. First record of five terrestrial snails in the State of Qatar. Turkish Journal of Zoology 34: 539-545.

Amr, Z. S., M. H. Najajreh, M. Zawahrah, E. Neubert, E. N. Handal, M. A. Abu Baker, and M. B. Qumsiyeh. 2018. Diversity and ecology of the land snails of the Palestinian Territories of the West Bank. Zoology and Ecology 28 (1): 25-35.

Auffenberg, K., and L. A. Stange. 1988. The Subulinidae of Florida. Florida Department of Agriculture and Consumer Services, Division of Plant Industry. Entomology Circular 305: 1-4.

Backhuys, W. 1966. Eobania in Bloemkool. Corr. Blad. Ned. Malac. Ver. 120: 1278.

Azzam, K. M. 2003. Description of the nematode Phasmarhabditis tawfiki n. sp. isolated from Egyptian terrestrial snails and slugs. Journal of the Egyptian-German Society of Zoology 42 (D): 79-87.

Baker, G. H. 2002. Helicidae and Hygromiidae as pests in cereal crops and pastures in southern Australia. In Molluscs as Crop Pests, edited by Barker, G. M., 193-215. $\mathrm{CAB}$ International.
Baker, G. H. 2008. The population dynamics of the Mediterranean snails Cernuella virgata, Cochlicella acuta (Hygromiidae) and Theba pisana (Helicidae) in pasture-cereal rotations in South Australia: a 20-year study. Australian Journal of Experimental Agriculture 48 (12): 1514-1522.

Baker, G. H., and B. G. Hawke. 1990. Life history and population dynamics of Theba pisana (Mollusca: Helicidae), in a cereal pasture rotation. Journal of Applied Ecology 27: 16-29.

Barker, G. M. 1999. Naturalised Terrestrial Stylommatophora (Mollusca: Gastropoda). Fauna of New Zealand 38: 254. Canterbury, New Zealand: Manaaki Whenua Press.

Benthem-Jutting, W. S. S. van. 1952. III. Critical revision of the Javanese pulmonate land-snails of the families Ellobiidae to Limacidae, with an appendix on the Helicarionidae. Treubia 21 (2): 291-435.

Bequaert, J., and W. J. Clench. 1936. A second contribution to the molluscan fauna of Yucatan. Carnegie Institution of Washington Publication 457: 61-75.

Bhavare, M. K., and S. R. Magare. 2017. Ecology and population studies of land slug, Laevicaulis alte in Shahada region. Journal of Applied and Advanced Research 2 (2): 63-66.

Bieler, R., and J. Slapcinsky. 2000. A case study for the development of an island fauna: recent terrestrial mollusks of Bermuda. Nemouria Occasional Papers of the Delaware Museum of Natural History 44: 1-100.

Bishara, S., M. S. Hassan, and A. S. Kalliny. 1968. Studies on some land snails injurious to agriculture in U. A. R. Revue de zoologie et de botanique africaines [Journal of African zoology and botany] LXXVII, 3-4: 239-252.

Bouaziz-Yahiatene, H., B. Pfarrer, F. Medjdoub-Bensaad, and E. Neubert. 2017. Revision of Massylaea Möllendorff, 1898 (Stylommatophora, Helicidae). ZooKeys 694: 109-133.

Brodie, G., and G. M. Barker. 2012. Laevicaulis alte (Férussac, 1822). Family Veronicellidae. USP Introduced Land Snails of the Fiji Islands Fact Sheet Series, 3.

Van Bruggen, A. C. 1981. Cochlicopa lubricella and Helix aspersa as alien land snails (Gastropoda, Pulmonata) in Zimbabwe/Rhodesia. Basteria 45 (4-5): 71-72.

Cameron, R. 2003. Land Snails in the British Isles. AIDGAP key, Occasional Publication 79. Preston Montford: Field Studies Council.

Capinera, J. L. 2017. Biology and food habits of the invasive snail Allopeas gracile (Gastropoda: Subulinidae). Florida Entomologist 100 (1): 116-123.

Čejka, T., M. Horsák, and L. Juřičková. 2014. A Mediterranean snail Eobania vermiculata (O. F. Müller 1774) in NW Germany. Malacological Bulletin [online]: http:// malbull.blogspot.com/2014/06/a-mediterranean-snaileobania.html

Charles, L., and A. Lenoble. 2020. Confirmation of Polygyra 
cereolus (Gastropoda: Polygyridae) in Puerto Rico, Greater Antilles. Novitates Caribaea 16: 159-163.

Chichester, L. F., and L. L. Getz. 1969. The zoogeography and ecology of arionid and limacid slugs introduced into northeastern North America. Malacologia 7: 313-346.

Cowie, R. H. 1996. New records of introduced land and freshwater snails in the Hawaiian Islands. Records of the Hawaii Biological Survey for 1995, part 2 (46): 25-27.

Cowie, R. H. 1997. Catalog and bibliography of the nonindigenous non-marine snails and slugs of the Hawaiian Islands. Bishop Museum Occasional Papers 50: $1-66$.

Cowie, R. H. 2000. Non-indigenous land and freshwater molluscs in the islands of the Pacific: conservation impacts and threats. In Invasive species in the Pacific: A technical review and draft regional strategy. South Pacific Regional Environmental Programme.

Cowie, R. H., R. T. Dillon, D. G. Robinson, and J. W. Smith. 2009. Alien non-marine snails and slugs of priority quarantine importance in the United States: A preliminary risk assessment. American Malacological Bulletin 27: 113-132.

Crowley, T. E. 1978. Island life: St. Helena. Journal of Conchology 29: 233-237.

Curry, P. A., and N. W. Yeung. 2013. Predation on endemic Hawaiian land snails by the invasive snail Oxychilus alliarius. Biodiversity and Conservation 22: 3165-3169.

Das, B., and L. Parida. 2015. Morphometric studies of the tropical leatherleaf slug Laevicaulis alte from Prachi belt of Odisha. Journal of Entomology and Zoology Studies 3 (3): 132-134.

Daoud, M. I. A. 2004. Ecological and morphological studies on some terrestrial snails in Dakahlia governorate. M. Sc. Thesis Agriculture Faculty Al-Azhar University.

Davis, P., M. Widmer, and T. Craven. 2010. Pest snails and slugs of Western Australia. Garden note. Government of Western Australia, Department of Agriculture and food. Note: 11. Farm note: 112/94: 4.

Desoky, A. S. S. 2018. Identification of terrestrial gastropods species in Sohag governorate, Egypt. Archives of Agriculture and Environmental Science 3 (1): 45-48.

Desoky, A. S. S., A. A. Sallam, and T. M. M. Abd ElRahman. 2015. First record of two species from land snails, Monacha obstracta and Eobania vermiculata in Sohag governorate, Egypt. Direct Research Journal of Agriculture and Food Science 3 (11): 206-210.

Desouky, M. M. A., and S. Busais. 2012. Phylogenetic relationships of the land snail; Eobania vermiculata (Müller, 1774) from Egypt and Saudi Arabia. A combined morphological and molecular analysis. The Journal of Basic and Applied Zoology 65: 144-151.

Dourson, C. D. 2013. Land Snails of the Great Smoky
Mountains National Park and Southern Appalachians. Goatslug Publications 343 pp.

Dvořák, L., and L. Kupka. 2007. The first outdoor find of an American snail Zonitoides arboreus (Say, 1816) from the Czech Republic. Malacologica Bohemoslovaca 6: $1-2$.

Ekin, I., and R. Şeşen. 2018. A new record of three-band garden slug Ambigolimax valentianus (A. Férussac, 1822) (Gastropoda: Limacidae) from Turkey. Turkish Journal of Zoology 42: 475-479.

El-Alfy, N. Z., K. A. Al-Ali, and A. H. Abdel-Rehim. 1994. Karyotype, meiosis and sperm formation in the land snail Macrochlamys indica. Qatar University Science Journal 14 (I): 122-128.

El-Deeb, H. I., G. M. Shereef, N. H. Essa, and M. M. Fouad. 1996a. Survey and distribution of land mollusca of some nurseries at greater Cairo, Egypt. Journal of Agricultural Sciences Mansoura University 21 (12): 4525-4535.

El-Deeb, H. I., E. M. Ghamry, N. El-Hwashy, and N. Essa. 1996b. Relative abundance of some land snails in certain Governorates of Egypt. Journal of Agricultural Sciences Mansoura University 21 (8): 2977-2983.

El-Deeb, H. I., M. Wilson, and E. H. Eshara. 1999. Ecological studies on certain land snails infest some Economic crops at Beheira governorate, Egypt. Proceedings of $2^{\text {nd }}$ International Conference Pest Control, Mansoura, Egypt: 19-28.

El-Deeb, H. I., A. Abdel-Halim, I. Koutb, F. K. Khidr, and N. M. Edress. 2004. Studying some ecological aspects associated with the prevalent land snails at Kafr El Sheikh governorate. Journal of Agricultural Science Mansoura University 29: 2847-2853.

Ellis, A. E. 1951. Census of the distribution of British nonmarine mollusca. Journal of Conchology, London 23: 171-244.

El-Okda, M. M. K. 1979. Land snails of economic important at Alexandria region with some notes on the morphological features classification, economic damage and population on the ornamental plants. Agricultural Research Review 57 (1): 12-130.

El-Okda, M. M. K. 1980. Land snails of economic importance on vegetable crops at Alexandria and neighboring regions. Agricultural Research Review 58 (1): 79-86.

El-Okda, M. M. K. 1981. Locomation activity and infestation abundance of certain terrestrial mollusca in fruit orchard, Alexandria province, ARE. Proceedings of $4^{\text {th }}$ Arab Pesticides Conference, Tanta University, Egypt 2: 279-287.

El-Okda, M. M. K. 1984. Land mollusca infestation and chemical control in El-Ismaelia governorate. Agricultural Research Review, Egypt 62: 87-92.

El-Okda, M. M. K., H. Mesbah, and A. H. El-Sebae. 1977. Land snails of economic importance at Alexandria region. I. Distribution and different injured host plants 1st Arab Biol. Cong., Alexandria 22-30 October. 
El-Wakil, B. H. 1999. Molluscicidal activity and repellency of some inorganic fertilizers against terrestrial snail, Theba pisana (Müller), infesting citrus trees in Northern Areas, Egypt. Journal of King Abdulaziz UniversityScience 11: 15-26.

Eshra, E. H. 2004. Studies on terrestrial mollusca at some governorates of West Delta with special reference to its integrated management. Ph. D. Thesis, Faculty of Agriculture, Al Azhar University, Egypt.

Eshra, E. H. 2013. Survey and distribution of terrestrial snails in fruit orchards and ornamental plants at Alexandria and EL-Beheira governorates, Egypt. Alexandria Science Exchange Journal 34 (2): 242-248.

Fechter, R., and G. Falkner. 1990. Weichtiere. Europäische Meeres- und Binnenmollusken. München: [Mollusks. European marine and inland mollusks]. Munich: Mosaik Verlag GmbH, 287 pp.

Feulner, G., and S. A. Green. 2003. Terrestrial molluscs of the United Arab Emirates. Mitteilungen der Deutschen Malakozoologischen Gesellschaft [Announcements from the German Malacoological Society] 69 (70): 23-34.

Feulner, G., E. Neubert, and S. A. Green. 2005. Land snails. In The Emirates. A natural history, edited by P. Hellyer, and S. Aspinall, 222-226. Trident Press Limited.

Forcart, L. 1953. The Veronicellidae of Africa (Mollusca, Pulmonata). Annales du Musée Royal du Congo Belge, Tervuren (Belgique). Série in-8, Sciences Zoologiques [Annals of the Royal Museum of the Belgian Congo, Tervuren, Belgium. Series in-8, Zoological Sciences] 23: 1-110, pl. I-V.

Forsyth, R. G. 1999. Terrestrial Gastropods of the Columbia Basin, British Columbia. Living Landscapes, Royal British Columbia Museum, 133 pp.

Frank, T. 1998. Slug damage and number of slugs (Gastropoda: Pulmonata) in winter wheat in fields with sown wildflower strips. Journal of Molluscan Studies 64: 319-328.

Gazzy, A. A., N. M. Mostafa, and W. A. Shahawey. 2019. Survey, population dynamics and estimation of damage of common land snail species on some vegetable plants and Egyptian clover at some regions at Kafr El-Sheikh governorate. Journal of Plant Protection and Pathology, Mansoura University 10 (1): 13-18.

Genena, M. A. M. 2003. Studies on the terrestrial gastropods at Dakahlia governorate. M. Sc. Thesis, Faculty of Agriculture, Mansoura University, Egypt.

Gittenberger, E., and T. E. H. Ripken. 1987. The genus Theba (Mollusca, Gastropoda, Helicidae). Systematics and distribution. Zoologische Verhandelingen [Zoological Treatises] 241: 1-59.

Godan, D. 1979. Schadschnecken und ihre Bekämpfung [Harmful snails and their control]. Ulmer, Stuttgart, Germany, 467 pp.

Godan, D. 1983. Pest slugs and snails, biology and control. Berlin, Germany: Springer-Verlag, 445 pp.
Gomes, S. R., and J. W. Thomé. 2004. Diversity and distribution of the Veronicellidae (Gastropoda: Soleolifera) in the Oriental and Australian biogeographical regions. Memoirs of the Queensland Museum 49 (2): 589-601.

Grimm, F. W., R. G. Forsyth, F. W. Schueler, and A. Karstad. 2010. Identifying land snails and slugs in Canada: introduced species and native genera. Quebec, Canada: Canadian Food Inspection Agency.

Gümüş, B. A., and E. Neubert. 2009. The Biodiversity of the Terrestrial Malacofauna of Turkey - Status and Perspectives. ZooKeys 31: 105-117.

Hanna, G. D. 1966. Introduced mollusks of western North America. Occasional Papers of the California Academy of Sciences 48: 1-108.

Hashem, A. G., and M. E. El-Halawany. 1996. Egypt. In Citrus pest problems and their control in the Near East, edited by Morse, J. G., R. F. Luck, and D. J. Gumpf, FAO Plant Production and Protection Paper 135: 25-42.

Hashem, A. G., J. M. Nakhla, and A. W. Tadros. 1992. Seasonal fluctuation in population of the land snails on citrus tree in the northern reclaimed lands. Al-Azhar Journal of Agricultural Research 16: 325-340.

Hashem, A. G., J. M. Nakhla, A. W. Tadros, and M. A. Korashy. 1993. Monitoring land snails on sweet orange trees in Behera Governorate (Egypt). Zagazig Journal of Agricultural Research 20 (2A): 691-698.

Hausdorf, B. 2000. The genus Monacha in Turkey (Gastropoda: Pulmonata: Hygromiidae). Archiv für Molluskenkunde [International journal of Malacology] 128 (1/2): 61-151.

Hegab, A. M. I., E. M. Ghamry, S. A. A. El-Massry, and A. I. Hassan. 1999. Ecological studies on certain land snails in some localities at Sharkia Governorate. Zagazig Journal of Agricultural Research 26 (3B): 787-795.

Heller, J. 2009. Land snails of the land of Israel. Pensoft Series Faunistica 83: 1-360.

Herbert, D. G. 2010. The introduced terrestrial Mollusca of South Africa. SANBI Biodiversity Press Series 15: 108. South African National Biodiversity Institute, Pretoria.

Herbert, D. G. 1997. The terrestrial slugs of KwaZulu-Natal: diversity, biogeography and conservation. Annals of the Natal Museum 38: 197-239.

Herbert, D., and D. Kilburn. 2004. Field guide to the land snails and slugs of eastern South Africa. Pietermaritzburg: Natal. Museum, South Africa, 336 pp.

Horsák, M., L. Dvořák, and L. Juřičková. 2004. Greenhouse gastropods of the Czech Republic: current stage of research. Malacological newsletter 22: 141-147.

Hubricht, L. 1985. The distribution of the native land mollusks of the eastern United States. Fieldiana, Zoology, New Series 24: 1-191.

Ismail, S. A. A., S. A. A. El-Massry, M. M. Khattab, and 
A. S. Hassan. 2003. Daily activity and damage caused by Eobania vermiculata Müller (Gastropoda) in citrus orchards. Egyptian Journal of Agricultural Research 18: $1-6$.

Ittah, Y., and U. Zisman. 1992. Evaluation of volatile allyl alcohol derivatives for control of snails on cut roses for export. Pest Science 35: 183-186.

Kassab, A., and H. Daoud. 1964. Notes on the biology and control of land snails of economic importance in the U. A. R. The Agricultural Research Review 42: 77-98.

Kerney, M. P., and R. A. D. Cameron. 1979. A field guide of the land snails of Britain and north-west Europe. Glasgow: Wm. Collings \& Sons, 288 pp.

Kerney, M. P., R. A. D. Cameron, and J. H. Jungbluth. 1983. Die Landschnecken Nord-und Mitteleuropas [The land snails of Northern and Central Europe]. Hamburg/ Berlin: Verlag Paul Parey, 384 pp.

Kumburegama, N. P. S., and K. B. Ranawana. 2001. Identification of pest snails and slugs of vegetable crops in four districts of Sri Lanka. Proceedings of Annual Research Sessions, University of Peradeniya, Sri Lanka 6: 117.

Likhachev, I. M., and E. S. Rammel'mier. 1952. Terrestrial Fauna of the U.S.S. R. Translated from Russian, 1962. Jerusalem: Israel Program for Scientific Translations.

Lokma, M. H. E. 2007. Studies on some terrestrial gastropods injurious to field crops at Sharkia governorate. M. Sc. Thesis Faculty of Agriculture Zagazig University, Egypt.

Long, D. C. 1972. Zonatid snails (Gasteropoda: Pulmonata) introduced into Victoria, Australia. Memoirs of Museum Victoria 33 (14): 115-120.

Mahmoud, M. F., and M. H. M. Awad. 2008. Population density of certain land snail and slug species and their damage to some fields and vegetable crops. Egyptian Journal of Agricultural Research 86 (5): 1763-1772.

Mahrous, M. E., M. H. Ibrahim, and E. M. Abd El-Aal. 2002. Occurrence, population density and importance value of land snails infesting different crops in Sharkia Goernorate. Zagazig Journal of Agricultural Research 29 (2): 613-629.

Marambe, B., P. Silva, S. Ranwala, J. Gunawardena, D. Weerakoon, S. Wijesundara, L. Manawadu, N. Atapattu, and M. Kurukulasuriya. 2011. Invasive alien fauna in Sri Lanka: National list, impacts and regulatory framework. In Island Invasives: Eradication and Management, edited by Veitch, C. R., M. N. Clout, and D. R. Towns, 445-450. Gland, Switzerland: IUCN.

Metwally, A. M., H. A. Zedan, A. B. El-Saeid, and T. M. M. El-Akra. 2002. Ecological studies on certain land snails in Monofia and Gharbia governorate. Proceedings of $2^{\text {nd }}$ International Conference, Plant Protection Research Institute, Cairo, Egypt, 65-79.

Mienis, H. K. 1973. Eobania vermiculata (Müller) in Israel (Gastropoda, Helicidae). Argamon, Israel Journal of Malacology 4 (1): 9-10.
Mienis, H. K. 2002. Eobania vermiculata in Iran. Triton 6: 27.

Mohammed, G. R. 2015. Incidence of land snails inhabiting different vegetation at some governorates in North-East of Delta Egypt. Journal of Plant Protection and Pathology, Mansoura University 6 (6): 899-907.

Mohamed, M. I., and R. F. Ali. 2009. Reproduction and Life History in the Two Land Snails Monacha cartusiana (Müller) and Eobania vermiculata (Müller) (Helicidae: Mollusca) in the Laboratory. Animal Biology Journal 1 (2): 99-107.

Mohamed, M. I., and R. F. Ali. 2011. Laboratory studies on the terrestrial Marsh slug Deroceras laeve (Müller) (Agriolimacidae: Mollusca). Animal Biology Journal 2 (3): 133-142.

Mohamed, M. I., and R. F. Ali. 2013. Laboratory Observations on Biology of the Tawny Garden Slug Limax flavus (Linnaeus) (Limacidae: Mollusca). Animal Biology Journal 4 (1): 51-62.

Mumladze, L., and N. Paposhvili. 2016. A new addition to the malacofauna of Georgia - Eobania vermiculata is replenishing its range. Proceedings of the Institute of Zoology, XXV: 153-155.

Muratov, I. V. 1998. Land mollusks of the Kopet Dagh Range: fauna, ecology, zoogeography. Ruthenica 8 (2): 137-145.

Nakhla, J. M., and A.W. Tadros. 1995. Studies on the seasonal abundance of land snails on date palm shoots in Sharkia governorate. Egyptian Journal of Agricultural Research 73 (2): 347-355.

Naser, D. M. 2010. New record of the land snail Allopeas gracilis (Hutton, 1834) (Gastropoda: Subulinidae) from Basrah area, Iraq. Jordan Journal of Biological Sciences 3 (2): 55-56.

Navarro-Barrachina, S., A. López Alabau, A. Pérez Ferrer, R. Ruiz Jarillo, and S. Quiñonero-Salgado. 2012. Sobre la presencia de Polygyra cereolus (Mühlfeld, 1816) (Gastropoda: Polygyridae) en España [On the presence of Polygyra cereolus (Mühlfeld, 1816) (Gastropoda: Polygyridae) in Spain]. Spira 4: 169-170.

Neubert, E. 1995. Two species of land snails in Saudi Arabia. Malacological Review 28: 125-126.

Neubert, E. 1998. Annotated checklist of the terrestrial and freshwater molluscs of the Arabian Peninsula with descriptions of new species. Fauna of Arabia 17: 333-461.

Neubert, E., and M. Bariche. 2013. On the Monacha species of Lebanon (Gastropoda, Hygromiidae). ZooKeys 311: 1-18.

Neubert, E., Z. S Amr, W. Waitzbauer, and H. Al Talafha. 2015. Annotated checklist of the terrestrial gastropods of Jordan (Mollusca: Gastropoda). Archiv für Molluskenkunde [International Journal of Malacology] 144 (2): 169-238.

Perez, K. E. 2008. Polygyridae (43-48). In A guide for 
terrestrial gastropods identification, edited by Perez, K. E., and R. J. Cordeiro. Carbondale, Illinois: American Malacological Society.

Petney, T. N., and H. C. Huset. 1992. A species and distribution list of land snails of Jordan. Argamon. Israel Journal of Malacology 10: 1-14.

Pilsbry, H. A. 1940. Land Mollusca of North America (North of Mexico). Academy of Natural Sciences of Philadelphia, Monographs (3), 1 (2): 575-994, i-ix.

Pilsbry, H. A. 1946. Land mollusca of North America (North of Mexico). Academy of Natural Sciences of Philadelphia 2 (1): 520.

Pilsbry, H. A. 1948. Land Mollusca of North America (North of Mexico). Academy of Natural Sciences of Philadelphia, Monographs (3), 2 (2): 521-1113.

Puizina, J., Ž. Fredotović, I. Šamanić, T. Šušnjara, L. Kekez, D. Cukrov, and G. Pleslić. 2013. Phylogeography of the Land Snail Eobania vermiculata (O.F. Müller, 1774) (Gastropoda: Pulmonata) along the Croatian Coast and Islands. Journal of Entomology and Zoology Studies 1 (4): $23-31$.

Rady, G. H., A. A. Abd-El Gawad, S.A.A. Ismail, and M. H. Lokma. 2014. Ecology of some terrestrial molluscs in Sharkia and Ismailia governorate. Egyptian Journal of Agricultural Research 92 (3): 907-920.

Ramzy, R. R. 2009. Biological and ecological studies on land snails at Assiut, Egypt. M.Sc. thesis, Assiut: Assiut University, Egypt.

Rashed, A. A. 2008. A new parasitic metacercaria from the land snail Monacha obstructa Pfeiffer 1842 with critical review on relevant metacercaria belonging to the genus Brachylaima Dujardin 1843. Journal of the Egyptian Society of Parasitology 38 (2): 483-500.

Rashed, A. A., M. Q. Wanas, A. M. Al Shareef, M. N. Al Attar, A. A. Sabry, and T. A. Morsy. 1995. The histopathological effect of metacercariae of the genus Brachylaima on the land snail, Monacha obstructa. Journal of the Egyptian Society of Parasitology 25 (2): 535-42.

Raut, S. K., and R. N. Mandal. 1984. Natural history of the garden slug Laevicaulis alte. Journal of the Bengal Natural History Society 3: 104-105.

Raut, S. K., and A. Panigrahi. 1989. Diseases of Indian pest slugs and snails. Journal of Medical and Applied Malacology 1: 113-121.

Ray, H. C., and A. Mukherjee. 1963. Fauna of Rajasthan, India. Part 3. Mollusca. Records of the Zoological Survey of India 61: 403-435.

Rehder, H.A. 1966. The non-marine mollusks of Quintana Roo, Mexico with the description of a new species of Drymaeus (Pulmonata: Bulimulidae). Proceedings of the Biological Society of Washington 79: 273-296, fig. 1-20.

Robinson, D. G., and R. G. Hollingsworth. 2009. Survey of slug and snail pests on subsistence and garden crops in the Islands of the American Pacific: Guam, and the
Northern Mariana Islands. Part 2. The Federated States of Micronesia; and American Samoa, with special reference to Samoa, Survey of slug and snail pests in the American Pacific, Project report. Internal Report for U.S. Department of Agriculture and the Government of Mariana Islands, $15 \mathrm{pp}$.

Ronsmans, J., and T. Van den Neucker. 2016. A persistent population of the chocolate-band snail Eobania vermiculata (Gastropoda: Helicidae) in Belgium. Belgium Journal of Zoology 146 (1): 66-68.

Roth, B., and C. M. Hertz. 1997. Recent records of Cochlicella Barbara (Linnaeus, 1758) (Hygromiidae) in Southern and Central California. The Festivus XXIX (9): 81-83.

Roth, B., and P. S. Sadeghian. 2003. Checklist of the land snails and slugs of California. Santa Barbara Museum of Natural History, Contributions in Science 3: 1-81.

Rowson, B., J. Turner, R. Anderson, and B. Symondson. 2014. Slugs of Britain and Ireland. Identification, understanding and control. FSC Publications: 136.

Sacchi, C. F. 1955. Biogeografia e polimorfismo nelle Euryparypha (Helicidae) del Marocco occidentale. Nota preliminare. [Biogeography and polymorphism in the Euryparypha (Helicidae) of western Morocco. Preliminary note]. Atti della Società Italiana di Scienze naturali [Proceedings of the Italian Society of Natural Sciences] 94: 85-95.

Sakovich, N. J., J. B. Bailey, and T.W. Fisher. 1984. Decollate Snails for Control of Brown Garden Snails in Southern California Citrus Groves. UC ANR Pub 21384. Oakland, CA.

Sallam, A., and N. El-Wakeil. 2012. Biological and Ecological Studies on Land Snails and Their Control. Integrated Pest Management and Pest Control - Current and Future Tactics 18: 413-444.

Sanderson, G., and W. Sirgel. 2002. Helicidae as pests in Australian and South African grapevines. In Molluscs as Crop Pests, edited by Barker, G. M., 255-270. CAB International.

Shahawy, W. A., A. S. Hendawy, A. E. Abada, and A. A. Kassem. 2008. Land snails infesting rice plants and their accompanied parasitoids and predators at Kafr El Sheikh governorate, Egypt. Egyptian Journal of Agricultural Research 86: 971-980.

Smith, B. J., and A. J. Dartnall. 1976. Veronicellid slugs in the Northern Territory with notes on other land molluscs. Journal of the Malacological Society of Australia 3 (3-4): 186.

Smith, B. J., and R. C. Kershaw. 1979. Field guide to the non-marine molluscs of south eastern Australia. Canberra: Australian National University Press, 285 pp.

South, A. 1992. Terrestrial slugs: biology, ecology, and control. London, UK: Chapman \& Hall.

Stojnić, B., M. Vukša, G. Jokić, and M. Čkrkić. 2011. First record of introduced Valencia Slug, Lehmannia 
valentiana (Férussac, 1822), in Serbia. Pesticides Phytomedicine (Belgrade) 26 (3): 213-220.

Spencer, H. G., B. A. Marshall, and R. C. Willan. 2009. Checklist of New Zealand living Mollusca. In New Zealand inventory of biodiversity. Volume one. Kingdom Animalia: Radiata, Lophotrochozoa, Deuterostomia, edited by Gordon, D. P., 196-219. Canterbury University Press, Christchurch.

Strecker, J. K. Jr. 1935. Land and fresh-water snails of Texas. Transactions of the Texas Academy of Sciences 17: 5-43.

Ueshima, R. 2006. The effect of pest control on Eobania vermiculata (Gastropoda: Helicidae) in Urayasu, Chiba Prefecture, Japan. Chiribotan 36 (4): 123.

Ueshima, R., M. Okamoto, and Y. Saito. 2004. Eobania vermiculata, a land snail newly introduced into Japan. Chiribotan 35: 71-74.

Wanas, M. Q., A. A. Rashed, A. M. Al Shareef, M. N. Al Attar, and H. M. Abdalla.1995. Morphological and anatomical studies on larval trematode of genus Brachylaima (Brachylaimidae) from the land snail, Monacha obstructa. Journal of the Egyptian Society of Parasitology 25 (2): 407-15.
Weltes-Schultes, F. W. 1998. Human-dispersed land snails in Crete, with special reference to Albinaria (Gastropoda: Clausiliidae). Biologia Gallo-hellenica 24 (2): 83-106.

Welter-Schultes, F.W. 2012. European non-marine molluscs, a guide for species identification. P. A1-A3, 1-1-679, Q1-Q78. Göttingten (Planet Poster Editions).

Wiktor, A.1983. Some data on slugs of Marocco and Algeria with description of a new Deroceras species. Malakologische Abhandlungen 8 (13): 155-166.

Wiktor, A. 2000. Agriolimacidae (Gastropoda: Pulmonata) a systematic monograph. Annates Zoologici 49: 347-590.

Wiktor A., C. De-niu, and M. Wu. 2000. Stylommatophoran slugs of China (Gastropoda: Pulmonata) - prodromus. Folia Malacologica 8 (1): 3-35.

Wu, S. P., C. C. Hwang, H. M. Huang, H. W. Chang, Y. S. Lin, and P. F. Lee. 2007. Land Molluscan Fauna of the Dongsha Island with Twenty New Recorded Species. Taiwania 52 (2): 145-151.

Yildirim, M. Z., Ü. Kebapçi, and B. A. Gümüs. 2004. Edible snails (terrestrial) of Turkey. Turkish Journal of Zoology 28: 329-335. 